\title{
The short- and long-run inconsistency of the expansionary austerity theory: a post-Keynesian/ evolutionist critique
}

\author{
Alberto Botta ${ }^{1}$ (iD \\ Published online: 12 March 2018 \\ (C) The Author(s) 2018
}

\begin{abstract}
This work provides a critical analysis of the expansionary austerity theory (EAT). The focus is on the theoretical weaknesses of the EAT - the extreme circumstances and fragile assumptions under which expansionary consolidations might take place. The paper presents a simple theoretical model based on both the post-Keynesian and the evolutionary/institutionalist schools. First, it shows that well-designed austerity measures hardly trigger short-run economic expansions in the context of expected longlasting consolidation plans dealing with remarkably high debt-to-GDP ratios, when the so-called "financial channel" is not operative (i.e. in the context of monetarily sovereign economies), or when the degree of export responsiveness to internal devaluation is low. Even in the context of non-monetarily sovereign countries (e.g. members of the eurozone), austerity's effectiveness crucially depends on its highly disputable capacity to stabilize immediately fiscal variables.

The paper then analyzes some possible long-run economic dynamics. Path dependency and cumulativeness make the short-run effects of fiscal consolidation elements of paramount importance to (hopefully) obtaining any medium-to-long-run benefit. Should these effects be even slightly contractionary, short-run costs can breed an endless spiral of recession and ballooning debt in the long run. If so, in the case of non-monetarily sovereign countries debt forgiveness may emerge as the ultimate solution to restore economic soundness. Alternatively, institutional innovations such as those adopted since mid-2012 by the European Central Bank are required to stabilize the economy, even though they are unlikely to restore rapid growth in the absence of more active fiscal stimuli.
\end{abstract}

Keywords Fiscal policy - Expansionary austerity theory $\cdot$ Post-keynesian/evolutionist macro models

Alberto Botta

A.Botta@Greenwich.ac.uk

1 Department of International Business and Economics, University of Greenwich, London, UK 
JEL classifications $\mathrm{E} 12 \cdot \mathrm{E} 61 \cdot \mathrm{E} 62$

\section{The theory of expansionary austerity (eat) and its critiques: An overview}

Expansionary austerity theory (EAT hereinafter) is part of a long-standing economic debate about the effectiveness of fiscal policy. Nonetheless, EAT as we currently know it emerged at the beginning of the 1990s. Most of the contributions in this strand of literature are empirical works based on some specific case studies (see Giavazzi and Pagano 1990; 1996; Perotti 2013) or larger cross-country data samples (see Alesina and Perotti 1995; 1997; Alesina and Ardagna 2010; 2012; Alesina et al. 2015). They adopt an inductive methodology, trying to validate a more general, supposedly universal, theory starting from the observation of a more or less timely and geographically delimited empirical evidence. EAT is characterized by four main postulates:

1. At least under certain circumstances, discretionary expansionary fiscal policies can induce economic contractions rather than expansions. In particular, this can happen when fiscal expansions generate quite large fiscal deficits, which in turn can impinge upon the solidity of public finances and cause an increase in interest rates. This non-Keynesian outcome of expansionary fiscal measures gets even more likely in the presence of an already high level of the public debt stock. ${ }^{1}$

2. Symmetrically, fiscal consolidations can prompt economic expansions, even in the short run and even in the midst of a recession, by squeezing public deficits, reducing the public debt stock, and creating the expectations for a more solid macroeconomic environment. In order to do so, however, fiscal consolidations must be well-designed. Not only the overall fiscal stance, but also the composition of specific fiscal measures matter.

3. A well-designed fiscal consolidation plan is based on a mix of deep, persistent and credible cuts in public expenditures then possibly followed by a reduction in taxes. According to Alesina and Perotti (1997), expenditure cuts in successful fiscal consolidations ("type-1 adjustments" in the jargon of the authors) "rely primarily on cuts in transfers, social security, government wages, and employment", whilst "tax increases are a small fraction of the total adjustment, and, in particular, taxes on households are not raised at all or are even reduced" (Alesina and Perotti 1997, p.211). This type of well-designed, supposedly expansionary, fiscal retrenchment is to be preferred to likely contractionary "type-2 adjustments", which "rely mostly on broad-based tax increases, and often the largest increases are in taxes on households and social security contributions" (Alesina and Perotti 1997, p.211). ${ }^{2}$

\footnotetext{
${ }^{1}$ See Sutherland (1997) for the case of possible non-Keynesian effects of expansionary fiscal measures when undertaken in a context of high public debt. Perotti (2013) also stresses that fiscal contractions may be expansionary in the presence of high interest rates, especially when they contribute to reducing risk premia on financial assets and prompt a considerable reduction in nominal interest rates, particularly with respect to government bonds.

${ }^{2}$ Alesina and Perotti (1997) also stress that spending cuts matched with (expected) reductions in household taxes may lead to expansionary outcomes by reducing workers' wage claims, by inducing wage moderation, and hence by increasing the external competitiveness of domestically produced goods.
} 
4. There are three channels through which a well-designed fiscal consolidation package can release expansionary outcomes. First, upfront public spending cuts can constitute a sign of a regime change that can positively affect the behavior of private economic actors, especially households, through the "expectation channel". Households can be induced to form optimistic expectations by anticipating future tax reductions and consequent increases in their own (permanent) income. This, in turn, may incentivize them to raise consumption immediately, giving momentum to current economic activity. Second, a "financial channel" is to be taken into account. Tough fiscal corrections that prove to be effective in reducing public deficit and the public debt stock can stimulate investment and growth by reestablishing bond vigilantes' trust in the solvency of public finances and prompting a significant reduction in interest rates. Third, an "export-led channel" may be at work. Cuts in public wages can establish a climate of wage moderation in the labor market, and engineer an internal devaluation of the real exchange rate. Thus, this can boost exports and ultimately growth. It goes without saying that this last channel is of particular relevance in countries adopting a fixed exchange rate regime or a supranational currency such as in eurozone member states.

The vast majority of the existing critiques of EAT have addressed the several shortcomings of the econometric techniques adopted by EAT supporters in order to validate their theoretical propositions empirically (see Guajardo et al. 2011; Baker and Rosnick 2014). The aim of this paper is different, since that it focuses on theory and aims at enquiring the logical solidity of EAT through a simple analytical postKeynesian/evolutionist model. More in detail, we intend to scrutinize two crucial propositions at the heart of EAT's policy proposal.

1. First, we critically investigate the assertion by Alberto Alesina, according to which "many even sharp reductions of budget deficits have been accompanied and immediately followed by sustained growth rather than recessions even in the very short run" (Alesina 2010, p.3). We perform such analysis in the short-run part of our model through two distinguished (for the sake of clarity) policy exercises. First, we detect whether a well-designed discretionary cut in public transfers followed by an expected reduction of taxes on households' income effectively increases the level of economic activity. Second, we test the logical soundness of the "expectation channel" by looking at the macroeconomic outcomes of a cut in the public sector's wages and, hence, of a EAT-type internal devaluation. We end up arguing that EAT theoretical foundations are extremely fragile. By no means can even a well-designed fiscal contraction easily conduct economic expansions. On the contrary, EAT's economic mechanisms are rather weak and state- and institutional-contingent, to say the least.

2. Second, we critically discuss the more recent idea that fiscal consolidations may imply short-term costs, but lead to far larger long-run benefits in the form of sound public finances and revived economic activity (see Section 3 on this point). We perform our analysis in the long-run part of the model by looking at some long-run dynamics possibly set in motion by austerity measures. We conclude noting that austerity-led short-run costs and long-run benefits are likely inconsistent. Even mild short-run recessionary responses to adjustment programs can give rise to 
instable evolutions in the public debt-to-GDP ratio, so that the short-run costs of austerity measures may eventually breed even larger long-run damages (rather than benefits).

Our model blends together the post-Keynesian and evolutionary/institutionalist traditions. From the post-Keynesian tradition, we take the demand-driven logic that permeates the functioning of our model. Moreover, we pay attention to the importance that mounting Keynesian-type radical uncertainty after the eruption of the global financial crisis and sovereign debt crisis in the eurozone may play in shaping economic actors' expectations and behaviors. According to the evolutionary approach to system dynamics (Radzicki and Sterman 1994), we describe an economy in which cumulative mechanisms give rise to path dependence and multiple equilibria. We also put emphasis on the crucial role that countryspecific institutions play in shaping diverging economic trajectories. We note that austerity may lead to different outcomes depending on the specific "monetary environment" in which it is implemented. Whilst the short-run expansionary outcomes of austerity hardly emerge in monetarily sovereign and non-monetarily sovereign countries alike, the way central banks intervene to stop financial distress proves to be a decisive factor in taming or feeding long-run macroeconomic instability. In the case of non-monetarily sovereign countries, in the absence of any deep institutional discontinuity, debt forgiveness may eventually stand out as the ultimate solution for restoring economic soundness. This fact notwithstanding, changes in monetary institutions' commitments taking place in the eurozone since mid-2012 show that economic variables and institutional factors often co-evolve in response to existing economic problems. Such an endogenous institutional change may eventually give rise to structural breakthroughs and set new and much more stable dynamics.

The paper is organized as follows. Section 2 develops the short-run part of our model and analyzes the effects of allegedly well-designed consolidation packages on economic activity and on the deficit-to-GDP ratio. Section 3 moves to the long run and shows how fiscal variables (and eventually economic institutions) may (co-)evolve as a consequence of (and perhaps in reaction to) the short-run effects assessed before. Section 4 concludes.

\section{Short-run expansionary/contractionary effects of fiscal adjustments in a simple open economy}

Post-Keynesian and evolutionary macro models always paid attention to the relevance of expansionary fiscal measures as useful policy tools for both short-run economic stabilization and long-run economic development. Nonetheless, interest in this topic has recently been renewed perhaps as a response to mainstream economists' post-crisis concern about the allegedly detrimental effects on economic growth of a too high public debt (see Reinhart and Rogoff 2010).

For instance, You and Dutt (1996) propose a post-Keynesian model in which they track the short-run and long-run effects of public expenditures and public debt accumulation on economic growth and income distribution. They find that a long-run 
increase in public debt stimulates growth by increasing interest incomes of bonds' holders, hence their consumption expenditures. ${ }^{3}$ Moreover, they also stress that larger fiscal deficits may be conducive to faster growth and lower income inequality if higher capacity utilization and higher employment rates raise workers' income more than capitalists/rentiers' do (due to increasing interest payments on a rising public debt stock). These findings remain valid in Dutt (2013), even though the author "makes a concession to orthodox economic thinking" (Dutt 2013, p.109) by allowing for a possible crowing-out effect of public debt on private investment. This is due to the fact that the expansionary effects of public expenditures, in particular, the crowding-in impact of public investment on private ones, are still at work, with positive consequences on economic activity, productivity dynamics and the growth rate of labor productivity. Eventually, these positive short- and long-run outcomes of fiscal expansions can more than compensate for any possible negative impact an increasing public debt may induce on entrepreneurs' will to invest.

Interestingly, You and Dutt (1996), Dutt (2013), as well as Leao (2013) also find that public debt dynamics can be stable and reach a steady-state (as a ratio of capital stock or GDP) even in the presence of a fiscal deficit, thanks to the abovementioned expansionary effects of a "larger" public sector. These results are confirmed by Godley and Lavoie (2007) and Ryoo and Skott (2013) in the context of full-fledged SFC models. In particular, Godley and Lavoie (2007) claim that the stability of the debt-to-GDP ratio can be preserved, even in the presence of interest rates higher than the GDP growth rates, without necessarily running a public budget surplus. Once again, this result stems from the fact that debt accumulation (as a ratio of GDP) can be selfstabilizing, since that its own growth also raises private sector's wealth and income (through interest payments), this way increasing consumption, GDP and tax revenues. In Hein (2016), such Keynesian-type expansionary effects of a higher growth rate of public expenditures give rise to a "paradox of debt": an increase in primary government deficits gives rise to a fall in the long-run stable public debt-output ratio.

All the above-mentioned works address the general topic of the effects of public debt accumulation on short- and long-run economic dynamics. Nevertheless, they do not directly and specifically criticize the crucial EAT's claims reported in the introduction of this paper. A number of other contributions try to do this. Boyer (2012), for example, surveys the very specific conjunctures under which austerity measures might have been expansionary in a few small open economies in the past. Nevertheless, Boyer does not provide any formal treatment of his critique. Palley (2010) elaborates a post-Keynesian closed-economy model showing the short-run effects of fiscal rules imposing limits to the debt-to-GDP ratio. Dosi et al. (2015) extend Palley's analysis through an evolutionary model featuring complex micro-macro interactions, and in which fiscal rules also entail long-run economic implications by affecting R\&D efforts and technology progress. Finally, Foresti and Marani (2014) propose a simple short-run model in which austerity may have expansionary outcomes depending on the accommodative stance

\footnotetext{
${ }^{3}$ It is often neglected in macro models that public debt and public bonds represent liabilities of the public sector but, at the same time, they are assets and a relevant component of private sector's wealth. A higher public debt and large interest payments to public bonds' holders may thus give rise to expansionary outcomes by simply stimulating private sector consumptions through income and wealth effects. These effects are fully accounted for by stock-flow-consistent (SFC) models such as those proposed by Godley and Lavoie (2007) and Ryoo and Skott (2013).
} 
monetary policy may take in the presence of fiscal retrenchments. Although more circumstantiated and specific, the critiques these contributions offer to the logic of the EAT are not fully convincing. Palley (2010) and Dosi et al. (2015), for instance, assume a simple closed economy in which, by default, EAT's "external channel" is inoperative. Also, they do not enter into the details of what is defined as a well-designed consolidation plan, ${ }^{4}$ so they neglect to consider how the composition of a fiscal contraction may affect its own outcomes. Similarly, Foresti and Marani (2014) simplistically define austerity as a reduction in the public deficit, thus taking for granted the debatable capability of restrictive fiscal measures to squeeze effectively the public deficit.

Differently from previous contributions, in this paper we develop a post-Keynesian/ evolutionist model that tries to enter more into the details of EAT's propositions. In a way, we take a step further with respect to Dutt (2013), and make some more concessions to orthodoxy. In particular, we more accurately model the specific components of a well-designed austerity package (see Section 2.1 below). In addition to that, we formally take into account all the three EAT channels through which wellconceived austerity measures could supposedly release their (expansionary) effects. In line with the purposes of the paper, we do this in order to show the intrinsic logical inconsistency between EAT assumptions about public debt dynamics and its allegedly negative effect on economic activity, and the suggested austerity measures aimed at avoiding public debt-led macroeconomic havoc.

We frame such analysis in the context of an economy that does not operate at full potential and does not face any supply-side constraint. Perhaps paradoxically, this assumption is consistent with the perspective put forward by the advocates of expansionary austerity. Sure, EAT's supporters argue that well-designed fiscal adjustments can boost economic activity through both demand and supply channels. Nonetheless, most of their emphasis is on the demand-side channels, given their attempt to stress their non-Keynesian perspective on the effects of fiscal policy. ${ }^{5}$ In line with this logic, we focus on the operativeness of the demand-side levers only, and we assume an economy in which fiscal policy may affect aggregate demand and, through this way, current economic activity.

\subsection{The model}

Let us assume an open economy composed of six sectors: working households, rentiers, (non-financial) firms, the government, commercial banks, and, ultimately, the "Rest of the world" (RoW henceforth).

Working households earn wages $(w)$ from non-financial firms. They consume domestic goods $(C)$, import foreign-made goods $\left(X M_{C}\right)$, and pay taxes according to the tax rate $(t)$. They also receive public transfers $\left(\operatorname{Tr}^{G}\right)$ and unemployment benefits

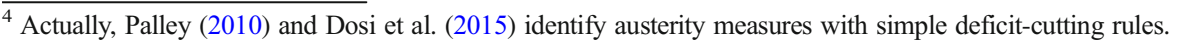

${ }^{5}$ Alesina et al. (2015) clearly point out that a decisive aspect of successful austerity packages lies in their capacity to stimulate private sector's investments by fostering private sector's confidence in the solidity of the domestic macroeconomic environment. Such a peculiar component of (successful) expenditure-based fiscal consolidations versus (unsuccessful) tax-based adjustments "cannot be explained by (accompanying) supplyside reforms" (Alesina et al. 2015, p.37). It implicitly relies upon the existence of a "negative" fiscal multiplier of aggregate demand.
} 
$(\bar{w} U)$ from the government. Working households' savings take the form of commercial banks' demand deposits $(B D)$.

Rentiers receive dividends from commercial banks, ${ }^{6}$ as well as interest payments on their holdings of foreign financial assets. For the sake of simplicity, we assume rentiers not to consume. Rentiers use their savings in order to accumulate new foreign financial assets according to a sort of Panama Papers-type investment fashion. New equity issuances are not considered in the present paper.

Non-financial firms pay wages to workers and make interest payments $\left(i_{H} L\right)$ on the stock of loans from commercial banks. They get revenues through workers' consumption expenditures, government purchases, exports to the RoW $(X E)$, and domestic gross capital formation (I). They import foreign goods in an amount equal to $X M_{I}$. For the sake of simplicity, we assume that realized profits $(\Pi)$ are fully retained in order to finance desired capital accumulation together with new loans $(d L)$ from commercial banks.

Commercial banks provide loans $(L)$ to domestic firms and buy domestic government bonds. Accordingly, they get interest payments $\left(i_{H} L\right)$ from domestic firms and $\left(i_{D} D^{H}{ }_{b}\right)$ from the government. Commercial banks receive deposits from households. We assume interest rates on households' deposits to be equal to zero. Commercial banks' profits are fully redistributed to rentiers. ${ }^{7}$

The government undertakes current consumption expenditures $(G)$, import foreign goods $\left(X M_{G}\right)$, and makes transfers to working households. It also levies taxes on working households' income (i.e. a crucial component of EAT-type austerity packages). For the sake of simplicity, we do not include taxes on rentiers' income or firms' profits (or indirect taxes) in our model. The difference between the government's revenues and total expenditures gives public surplus (or deficit). The public deficit is financed by issuing new government bonds $(B=d D)$. Both commercial banks and the RoW buy domestic government bonds.

The RoW sells imported goods in the amount $(X M)$ and buys exports $(X E)$. As to financial transactions, financial outflows are given by domestic rentiers' accumulation of new assets abroad. Financial inflows take the form of net purchases of new homegovernment bonds by the RoW (i.e., $B_{R o W}=d D_{R o W}^{H}$ ). Exchange rate fluctuations can significantly affect both trade and financial flows. For the sake of simplicity, here we depart from this complication and we take the nominal exchange rate as fixed. We rather focus on real exchange rate variations that, according to EAT, can take place due to fiscal policy-induced wage moderation and internal devaluation. In the same vein, the mechanisms through which the balance of payments (BoP) adjusts to equilibrium are not a major aspect of this model. Accordingly, we assume that current account deficit (surplus) and capital account surplus (deficit) always compensate each other, perhaps through the intervention of central banks (not explicitly model in this paper). For example, this is the case of trade and financial relations among eurozone countries,

\footnotetext{
${ }^{6}$ We assume rentiers to be the ultimate owners of commercial banks by holding commercial bank equities.

${ }^{7}$ In our simple model, commercial banks do not play any active role in the definition of income distribution, since commercial bank profits are fully distributed to rentiers. Nevertheless, they still remain a fundamental actor since the way they determine interest rates on loans to the private sector can crucially affect how austerity measures may affect investment demand and capacity utilization as a whole. See more on this here below.
} 
Table 1 Balance sheet matrix

\begin{tabular}{|c|c|c|c|c|c|c|c|}
\hline & Workers & Rentiers & Firms & Commercial Banks & Government & RoW & $\Sigma$ \\
\hline Capital & & & $+K$ & & & & $+K$ \\
\hline Deposits & $+B D$ & & & $-B D$ & & & 0 \\
\hline Gov. bonds & & & & $+D_{b}$ & $-D$ & $+D_{R o W}$ & 0 \\
\hline Loans & & & $-L$ & $+L$ & & & 0 \\
\hline Equities & & $+E_{b}$ & & $-E_{b}$ & & & 0 \\
\hline Foreign Assets & & $+F A$ & & & & $-F A$ & 0 \\
\hline Net Worth & $-N W_{H}$ & $-N W_{R}$ & $-N W_{F}$ & $-N W_{B}$ & $-N W_{G}$ & $-N W_{R o W}$ & $-K$ \\
\hline Total & 0 & 0 & 0 & 0 & 0 & 0 & 0 \\
\hline
\end{tabular}

in which ECB's Target-2 balance adjusts endogenously in order to ensure the equilibrium in the BoP.

All the economic and financial relations characterizing our economic system are reported in the Balance sheet matrix and Transactions-flow of funds matrix reported in Tables 1 and 2, respectively.

Let's assume that the economy produces according to a fixed-coefficient technique. Equation (1) defines the current level of economic activity $(Y)$ as a function of capacity utilization $\left(y=Y / Y^{*}\right),{ }^{8}$ the output-capital technological coefficient $\beta\left(=Y^{*} / K\right)$, and of the available capital stock $(K)$.

$$
Y=\frac{Y}{Y^{*}} \frac{Y^{*}}{K} K=y \beta K
$$

Given labor productivity $(\alpha)$ and the total labor force $(N)$, Eqs. (2) and (3) define the level of unemployment $(U)$ and the unemployment rate $(u)$, with $(\delta)$ as the ratio of potential output over the maximum amount of goods producible, according to labor productivity and the available labor force.

$$
\begin{gathered}
U=N-E=N-(Y / \alpha) \\
u=\frac{N-(Y / \alpha)}{N}=1-\frac{Y}{Y^{*}} \frac{Y^{*}}{\alpha N}=1-\delta y
\end{gathered}
$$

As far as the labor market is concerned, we assume workers and trade unions to target a desired real wage rate and, therefore, given labor productivity, a desired wage share $\left(1-\tau_{w}\right)$ (" $\tau_{w}$ " being the profit share implicitly consistent with trade unions' target). We assume the bargaining power of trade unions to depend positively on the degree of regulation and protection of workers in the labor market, say the generosity of

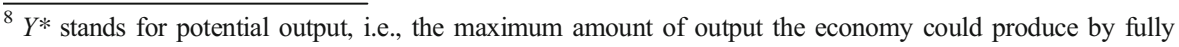
utilizing the available capital stock.
} 


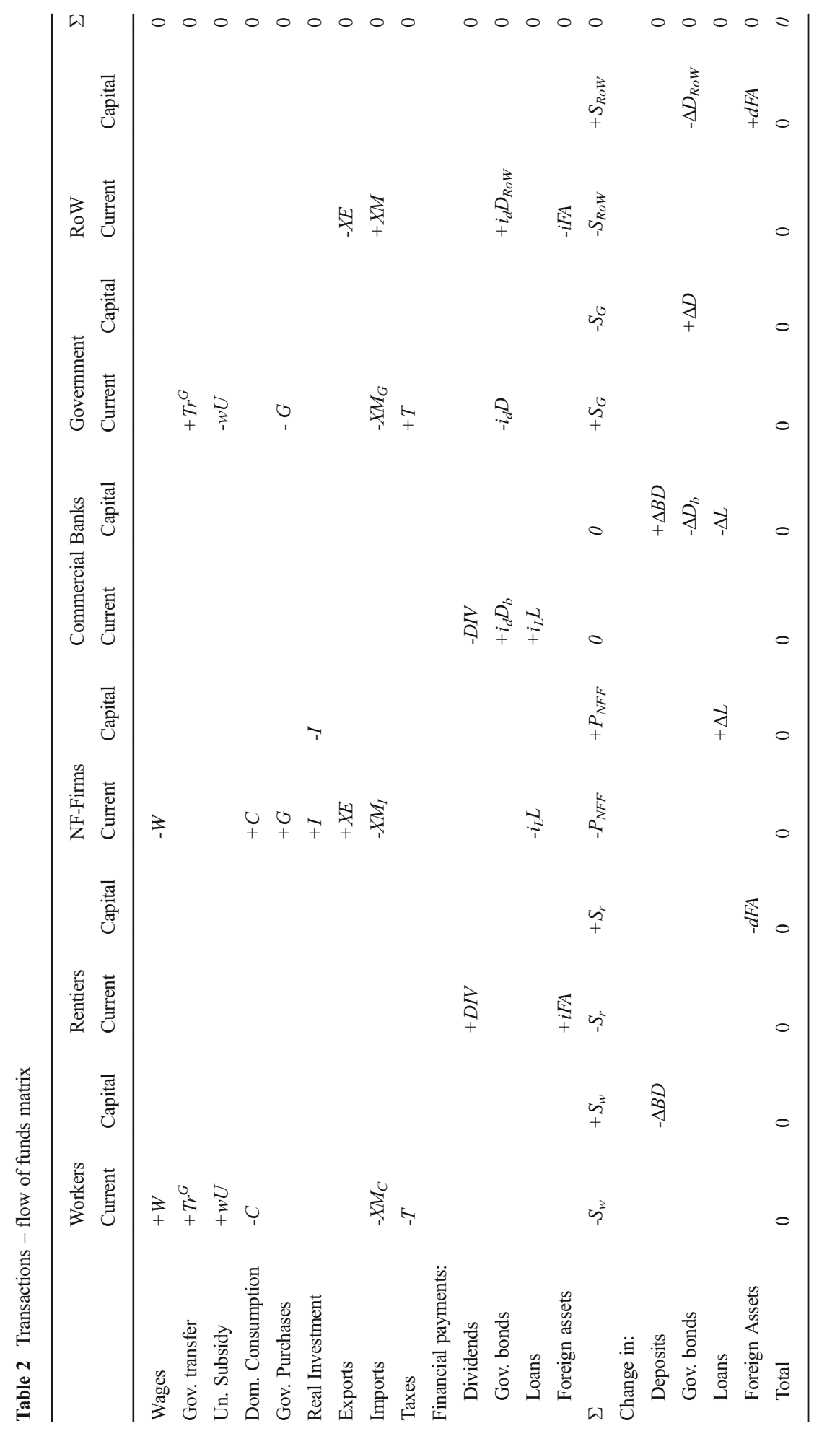


unemployment benefits $(\bar{w})$, among other factors. Accordingly, we assume $\left(1-\tau_{w}\right)$ to be a positive function of the "labor market regulation variable" ( $z$ ). Equation (4) defines the nominal wage rate $(w)$ bargained by trade unions on the basis of their targeted wage share and their price expectations $\left(P^{e}\right)$ :

$$
w=\left(1-\tau_{w}(z(\bar{w})) P^{e} \alpha\right.
$$

On their side, firms target a desired profit rate $\left(r^{d}\right)$. Given their expectations about the level of capacity utilization $\left(y^{e}\right)$ - see more on this below - they set the mark-up $(m)$ on variable costs and the ensuing profit share $(\tau)$ on domestic income consistently with their goals. Equations (5) and (6) formalize firms' behaviors as to the determination of the domestic price $\left(P^{H}\right)$ :

$$
r^{d}=\tau(m) y^{e} \text { hence } m=\tau\left(r^{d} / y^{e}\right)^{-1} \text { with }\left(\partial \tau / \partial r^{d}\right)>0 ;\left(\partial \tau / \partial y^{e}\right)<0
$$

$$
P^{H}=(1+m) w / \alpha
$$

In our open economy, Eqs. (5) and (6), together with foreign prices $\left(P^{F}\right)$ and the (given) nominal exchange rate $(e)$, determine the real exchange rate $(q)-$ see Eq. (7) below:

$$
q=\frac{e P^{F}}{P^{H}}=\frac{e P^{F}}{(1+m)\left(1-\tau_{w}\right) P^{e}}
$$

When we describe the components of aggregate demand in our model, we first assume aggregate consumption to depend on workers' disposable income only, whereas rentiers save all their income. This is a highly simplifying assumption that bears some important implications as to the inter-temporal dynamics of the public debt-toGDP ratio (see Section 3). Indeed, in our model, we exclude a priori any possible expansionary effect that debt accumulation may play on aggregate consumption by both increasing private sector's wealth (in this model, government bonds are directly held by commercial banks and foreigners only) and, more importantly, by increasing rentiers' income via higher interest payments. In the post-Keynesian models we reviewed at the beginning of this Section, such debt-driven expansion of domestic consumption significantly contributes to (self-) stabilize the debt-to-GDP ratio. With this caveat in mind, we adopted this assumption to maintain the model tractable and focused on its primary goal, i.e. the formalization of the main components of a "welldesigned" EAT-type austerity plan. Furthermore, our assumption represents one of the several concessions we make to EAT in order to reveal its intrinsic logical contradictions. Indeed, we will show more clearly in Section 4 that when public debt does not bear positive effects on economic activity and its dynamics can easily become unstable (hence orthodoxy's obsession for its stabilization through austerity), then the short-run costs of austerity (in terms of economic recession and a likely initial increase in the debt-to-GDP ratio) can hardly produce any long-run benefit. 
Equation (8) below formalizes out aggregate consumption function. Given the saving rate $(s)$ and the taxation rate $(t)$, domestic consumption is a positive function of wage bill $W(=w E)$, public transfers $\left(\operatorname{Tr}^{G}\right)$, and unemployment benefits $(\bar{w} U)$. More precisely, Eq. (8) defines consumption as normalized by the domestic capital stock, with $\omega\left(=w / P^{H}\right)$ and $\bar{\omega}\left(=\bar{w} / P^{H}\right)$ as the real wage rate and the real unemployment benefit (in terms of the home price $P^{H}$ ) - with $\omega>\bar{\omega}-$ and $\rho\left(=\operatorname{Tr}^{G} / P^{H} K\right.$ ):

$$
\frac{C}{P^{H} K}=c_{0}+\left(1-s\left(t^{e}, \operatorname{Tr}^{G}\right)\right)(1-t)\left[\frac{\beta(\omega-\bar{\omega}) y}{\alpha}\right]
$$

With $c_{0}=(1-s)(1-t)\left[\frac{\beta}{\alpha \delta} \bar{\omega}+\rho\right] ; f_{t^{e}}=\left(\partial s / \partial t^{e}\right)>0 ; f_{T r^{G}}=\left(\partial s / \partial T r^{G}\right)<0$.

In line with the literature on expansionary austerity, in Eq. (8) we also assume that households' saving propensity $(s)$ depends positively on the expected future tax rate $\left(t_{e}\right)$. This assumption relies upon a kind of orthodox "permanent income argument". Current cuts in public expenditures, if sufficiently strong and reliable, may induce households to increase current consumption, since they may expect a lower tax burden tomorrow. By the same token, we assume $(s)$ to depend negatively on public transfers. Indeed, it is reasonable to believe that a permanent cut in public transfers, perhaps due to the decision to downsize the provisions of the welfare system (read: a less-generous domestic pension system), can induce households to adopt a precautionary stance and save more today in anticipation of lower public transfers tomorrow. ${ }^{9}$

Equation (9) gives public purchases, once again normalized for the existing capital stock $K$, as an exogenous policy variable $(\gamma)$.

$$
\frac{G}{P^{H} K}=\gamma
$$

Equation (10) defines the current growth rate of the capital stock. For the sake of simplicity, following Taylor (2012), we assume that investment demand is purely autonomous in the short run, in the sense that it does not depend on current capacity utilization. We take this assumption in order to capture EAT's emphasis on role of economic actors' expectations. In fact, we imagine entrepreneurs to define desired investments according to their expectations about capacity utilization $\left(y^{e}\right)$. Entrepreneurs will increase investments should they expect the economy to expand and capacity utilization to be high. By contrast, they will scale down investment projects if negative expectations mature about contracting economic activity. Finally, we assume investment demand to be a negative function of the costs of external borrowing $\left(i_{L}\right)$. This assumption contributes to the formalization of the abovementioned "financial channel". Austerity measures can possibly expand private investments in the event they manage to downside the public deficit imbalances, and prompt a reduction in interest rates.

\footnotetext{
${ }^{9}$ The same logic may apply in the presence of a reduction in public benefits to unemployed people, which makes average expected income lower.
} 


$$
\frac{I}{K}=g\left(y^{e}, i_{L}\right) \text { with } g_{y^{e}}>0 \text { and } g_{i_{H}}<0
$$

Finally, Eq. (11) describes exports (as normalized with respect to the capital stock) to be a simple linear positive function of the real exchange rate $(q)$. Equation (12), in turn, assumes "normalized" imports as a linear (positive) function of domestic capacity utilization $(y)$, with parameter $(\eta)$ being a negative function of the real exchange rate $(q)$ :

$$
\begin{gathered}
\frac{E X}{P^{H} K}=\epsilon q \\
\frac{X M}{P^{H} K}=\eta(q) y \beta \text { with } \eta_{q}=(\partial \eta / \partial q)<0
\end{gathered}
$$

As to the "financial" side of the economy, let us first consider how private firms finance desired investments. In this model, we assume that non-financial firms retain all profits in order to fund capital accumulation. Additionally, they take loans from commercial banks $(d L)$ for the part of investments not covered by internal funds. In real life, it is obviously possible that commercial banks ration available credit so that not all investment projects are eventually financed. For the sake of simplicity, we do not take this eventuality explicitly into account. Nonetheless, commercial banks fix the interest rate $\left(i_{L}\right)$ charged on loans to nonfinancial firms. In periods of financial distress, commercial banks are very likely to increase the mark-up rate through which they determine $i_{L}$ (see more on this below). By doing this, they increase the cost of external funding, and implicitly cut the total amount of financed investment projects.

Commercial banks hold two types of assets on their balance sheet. On the one hand, they buy domestic government bonds. On the other hand, they give loans to firms. Government bonds are considered "relatively" safe assets. They constitute the collateral commercial banks commonly use in refinancing operations with the central bank, even in periods of financial turbulences in the market for sovereign bonds (see Mehrling 2011). On the contrary, loans stand out as "relatively" riskier. They are "non-shiftable" assets that, once created, will likely remain on commercial banks' balance sheets until maturity, together with the corresponding risk. Accordingly, in Eq. (13) we assume commercial banks to set the interest rate $\left(i_{L}\right)$ on loans to the private sector by applying a mark-up $(\mu)$ on the interest rate $\left(i_{d}\right)$ on government bonds.

$$
i_{L}=(1+\mu) i_{d}
$$

The public deficit $(d D)$ (hence new bond issuances) is given by the difference between government's outlays, i.e. public purchases $(G)$, public transfers $\left(\operatorname{Tr}^{G}\right)$, unemployment benefits $(\bar{w} U)$, and debt servicing $(\Psi)$, minus tax revenues: 
$d D=G+\operatorname{Tr}^{G}+\bar{w} U+\Psi-t\left[w E+\operatorname{Tr}^{G}+\bar{w} U\right]$. Equation (14) below expresses the public deficit as a ratio of current output:

$$
b=\frac{d D}{Y}=\left(\frac{d D}{P^{H} K}\right)\left(\frac{P^{H} K}{Y^{*}}\right)\left(\frac{Y^{*}}{Y}\right)=\frac{(\xi+\psi)}{\beta y}
$$

With $\xi=\frac{G+T r^{G}+\bar{w} U+\Psi-t\left[w E+T r^{G}+\bar{w} U\right]}{P^{H} K}=\gamma+(1-t)\left(\rho+\bar{\omega} \frac{G+T r^{G}+\bar{w} U+\Psi-t\left[w E+T r^{G}+\bar{w} U\right]}{P^{H} K}\right)$ $-[t \omega+(1-t) \bar{\omega}] \frac{G+T r^{G}+\bar{w} U+\Psi-t\left[w E+T r^{G}+\bar{w} U\right]}{P^{H} K} y$ as the primary deficit-to-capital stock ratio, and $\psi=\Psi / P^{H} K$ as the costs of debt servicing over the capital stock.

Finally, Eq. (15) formalizes how the interest rate on government bonds is determined in financial markets. Together with Eqs. (10) and (13), it models EAT's "financial channel":

$$
i_{d}=i+\sigma(b, \Omega)
$$

With $\sigma>0$ and $\sigma_{b}=(\partial \sigma / \partial b)>0$ if $\Omega=1 ; \sigma=0$ and $\sigma_{b}=0$ if $\Omega=0$

According to Eq. (15), yields on bonds depend on the perceived degree of soundness of public finances. Following De Grauwe (2011) and De Grauwe and Ji (2013), the riskiness of government bonds also relies upon the "monetary framework" in which government bonds are issued. Monetarily sovereign countries issue bonds denominated in their own currency, which is under the control of the corresponding central bank. Even more importantly, the central bank will likely intervene in financial markets any time it wants and buy government bonds in order to prevent default risks from emerging. As a consequence, in monetarily sovereign countries, government bonds are considered risk-free assets, and their yields are insensitive to most economic variables, public finance variables among others (see De Grauwe and Ji 2013). This is not the case of eurozone countries. Eurozone governments issue bonds denominated in a foreign supranational currency. On top of this, eurozone rules require national governments to find resources on private financial markets only, and forbid the European Central Bank (ECB) from buying public bonds (at least on the primary market). The solidity of eurozone countries' public finances is subject to the will of financial operators, who perceive eurozone government bonds as potentially riskier assets.

Consistent with these arguments, in Eq. (15), $(i)$ stands for the interest rate on riskfree assets. Parameter $(\sigma)$ represents a country-specific factor risk. It jointly depends on the state of public finances, and on a country-specific bivariate "monetary framework" variable $(\Omega=0$ or 1 ). We assume $\sigma$ to depend positively on the public-deficit-to-GDP ratio $(b) .{ }^{10}$ The higher $b$, the higher the interest rate $\left(i_{d}\right)$ a government has to pay on public bonds. However, this relationship holds true only in the case of non-monetarily sovereign economies, in which case $(\Omega)$ is equal to 1 . In the case of monetarily

\footnotetext{
${ }^{10}$ In the short-run part of the present model, we assume the interest rate $\left(i_{d}\right)$ to be a (positive) function of the public deficit-to-GDP ratio only, and not of the debt-to-GDP ratio. This is, of course, a simplifying assumption. Yet, whilst it makes mathematical passages more tractable, it does not change the meaning or the results of our analysis. This assumption will be relaxed in the long-run analysis performed in the second part of the paper.
} 
sovereign economies, $\Omega$ turns equal to 0 . The positive relations between $\left(i_{d}\right)$ and $(b)$ breaks down, so that $\sigma=0$ and $\sigma_{b}=0$. Yields on monetarily sovereign countries' government bonds are exogenously equal to $(i)$.

In our demand-driven model, aggregate demand determines production. Equation (16) defines the equilibrium on the goods market:

$$
Y=C+G+I+E X-X M
$$

Normalizing both sides Eq. (16) by the capital stock, plugging Eqs. (1) and (8)-(12) into (16) and rearranging, we get the value of capacity utilization $(y)$ that ensures equilibrium on the goods market.

$$
y=\frac{C_{0}+\gamma+g\left(y^{e}, i_{L}(b)\right)+\epsilon q}{\Lambda}
$$

With $\frac{1}{\Lambda}=\frac{1}{\beta\left[1-\frac{(1-S)(1-t)}{a}(\omega-\varpi)+\eta\right]}$ as the Keynesian multiplier. As expected, the Keynesian multiplier is a negative function of the saving rate $(s)$, the tax rate $(t)$, and the import coefficient $\eta(q)$. Also, the Keynesian multiplier increases with the real wage rate $(\omega)$. Equation (17) simple shows that capacity utilization is a positive function of all demand injections. In particular, it is worth noting that $(y)$ increases with public transfers $\rho$. Furthermore, higher real unemployment benefits $\bar{\omega}$ have a direct positive impact on $(y)$ by raising $\left(c_{0}\right)$ (despite its direct negative effect on the Keynesian multiplier). ${ }^{11}$ Note that the equilibrium level of capacity utilization is influenced by the government's public deficit $(b)$, via its possible effects on bonds' yields $\left(i_{d}\right)$ (see Eq. (15)) and, hence, $\left(i_{L}\right)$ and $(g)$ - see Eqs. (13) and (10). It is also worth noting that, according to Eq. (14), capacity utilization feeds back in the determination of the deficitto-GDP ratio.

\subsection{The short-run macroeconomic effects of cuts in public transfers}

According to the arguments presented in the previous section, we can now obtain a system of two equations in two unknown variables $(y, b)$ by putting together Eqs. (14) and (17). By solving this system, we simultaneously determine the short-run equilibrium values of capacity utilization and deficit-to-GDP ratio. More formally:

$$
\left\{\begin{array}{c}
y=\frac{C_{0}+\gamma+g\left(y^{e}, i_{L}(b)\right)+\epsilon q}{\Lambda} \\
b=\frac{(\xi(y)+\psi)}{\beta y}
\end{array}\right.
$$

System (18) is at the center of our fiscal policy "exercises".

\footnotetext{
${ }^{11}$ The direct effect of $(\bar{w})$ on $(y)$ does not take into account the indirect impact that $(\bar{w})$ may induce on capacity utilization by affecting wage determination, hence the real exchange rate and export and import flows (see more on this in section 2.3).
} 
Exercise 1 The government implements a restrictive fiscal policy such that the cyclically adjusted primary deficit over GDP ( $\left.b^{*}\right)$ decreases by an amount equal to $-\theta$ (i.e. $\mathrm{db}^{*}=-\theta$ and $\left.\theta>0\right){ }^{12}$ Fiscal consolidation is carried out through a cut to public transfers (i.e., $\mathrm{dTr}^{\mathrm{G}}<0$ ). Consistent with EAT logic, as a consequence of public transfers cut, economic actors expect a reduction in future taxes in an amount equal to $\mathrm{dt}^{\mathrm{e}}$, with $\left(\mathrm{dt}^{\mathrm{e}}<0\right)$.

For the purpose of this exercise, we define $\left(b^{*}\right)$ as the primary deficit that would emerge should output be at full capacity, i.e. $Y=Y^{*}$ and $y=1$. According to Eq. (14), $b^{*}$ is then equal to: $b^{*}=\frac{1}{\beta}\left[\gamma+(1-t)\left(\rho+(1-\delta) \bar{\omega} \frac{1}{\beta}\right)-t \omega \frac{1}{\beta}\right]$. According to the design of our fiscal policy exercise, we finally get: $d b^{*}=-\theta=\frac{(1-t)}{\beta} d \rho=\frac{(1-t)}{\beta} d \operatorname{Tr}^{G}$, so that: $d \operatorname{Tr}^{G}=-\frac{Y^{*}}{(1-t)} \theta$.

Take now system (18) and totally differentiate it with respect to $d \operatorname{Tr}^{G}$ and $d t^{e}$. We obtain:

$$
\left\{\begin{array}{c}
d y=\frac{1}{\Lambda}\left\{y_{T^{G}} \theta+y_{t^{e}}\left|d t^{e}\right|+g_{b} d b\right\} \\
d b=-\frac{1}{\beta y}\left[\beta \theta+\left(1+\left|\varepsilon_{\xi, y}\right|\right) \frac{\xi}{y} d y\right]
\end{array}\right.
$$

In system (19), we define $y_{T r^{G}}=\left[f_{T^{G}} \frac{c_{0}}{(1-s)(1-t)} Y^{*}-(1-s) \beta+\frac{c_{0}}{(1-s)(1-t)} Y\right]<0$ as the negative effect that a cut of public transfers carries on private consumption and capacity utilization. In turn, $y_{t^{e}}=\left[f_{t^{e}} \frac{c_{0}}{(1-s)}+\left(\partial \Lambda / \partial t^{e}\right) y\right]>0$ is the positive effect that an expected reduction in taxation $\left|d t^{e}\right|>0$ brings about current consumption and, hence, economic activity. Finally, $g_{b}=g_{i_{L}}(1+\mu) \sigma_{b}<0$ is the negative effect that an increase in the public deficit (with respect to the GDP) would induce on private investment by affecting interest rates $\left(i_{d}\right)$ and $\left(i_{L}\right)$. In the equation for the change in the deficit-to-GDP ratio, $\left(\varepsilon_{\xi, y}\right)$ is the (negative) elasticity of primary deficit with respect to capacity utilization.

Equations (20) and (21) give the solutions $d y^{S}$ and $d b^{S}$ of system (19) once we make explicit the positive/negative signs of the "partial" effects just described according to the positive/negative variations in the policy variables $\left(d T r^{G} ; d t^{e}\right)$ at the center of our policy exercise:

$d y^{S}=\frac{\overbrace{y_{t^{e}}\left|d t^{e}\right|}^{\text {expectation channel:(+ or } 0)}-\overbrace{\left|y_{T r} g\right| \theta}^{\text {transfer-cut effect: }}(-)+\overbrace{\left|g_{b}\right|(1 / y) \theta}^{\text {financial channel: }(+ \text { or } 0)}}{\left[\Lambda-\frac{\left|g_{b}\right|}{\beta y}\left(1+\left|\varepsilon_{\xi, y}\right|\right) \frac{\xi}{y}\right]}$

$$
d b^{S}=-\frac{1}{\beta y}\left[\beta \theta+\left(1+\left|\varepsilon_{\xi, y}\right|\right) \frac{\xi}{y} d y^{S}\right]
$$

\footnotetext{
${ }^{12}$ We focus on the cyclically adjusted primary balance because this is the economic variable EAT's supporters mostly use in order to measure the extent of discretionary fiscal policies.
} 
Equations (20) and (21) show that even well-designed austerity measures hardly guarantee that austerity-led expansion will materialize, even in a theoretical framework that makes several concessions to EAT's orthodoxy. By the same token, there is by no means any guarantee that well-designed austerity can effectively reduce the debt-toGDP ratio. More in detail:

1. The "expectation channel" can induce an expansionary effect on private consumption only if $\frac{\left|d t^{e}\right|}{\theta}>\frac{\left|d t^{e}\right|}{\theta}$, i.e. the expected reduction in taxation, is sufficiently large so that it more than compensates for the contraction in private consumption due to current and certain cuts in public transfers. Households' expectations are crucial. Paradoxically, it is reasonable to think that such positive expectations will hardly materialize in an economy characterized by a high public debt, i.e. the economic scenario in which fiscal consolidation is primarily needed according to EAT's supporters. When the public debt $(D)$ is considerably high, a prolonged period of fiscal consolidation is likely foreseen, and a high degree of uncertainty may "surround" the extent and the timing of future tax cuts. In such a context, the "expectation channel" is extremely weak at best, and likely overwhelmed by the contractionary effect of cuts in public transfers.

2. Following Eqs. (13) and (15), in monetarily sovereign countries, the "financial channel" may be irrelevant $\left(\sigma_{b}=0\right)$, so that another alleged expansionary effect of well-designed fiscal consolidation may actually vanish.

3. The "financial channel" might be at work in the case of non-monetarily sovereign (eurozone) countries. In such a context, one could be persuaded that front-loaded fiscal adjustments might create a favorable environment for growth if they effectively put fiscal variables under control, and reassure financial markets about the sustainability of the fiscal stance. Yet, we are very far from taking such an outcome of fiscal consolidation as guaranteed. Indeed, some recent empirical evidence shows that severe fiscal retrenchments may rather induce a short-run deterioration in fiscal variables by jeopardizing growth (see Ali Abbas et al. 2013). In terms of our model, Eq. (21) shows that austerity measures can surely prompt a reduction in the public deficit-to-GDP ratio only if they engineer an expansion of the economy (i.e. $d y^{S}>0$ ). If this does not happen, austerity measures could still reduce the public deficit, and ignite a virtuous financial mechanism only on the condition that economic contraction is small, so that:

$$
\frac{\left|d y^{S}\right|}{\theta}<\frac{\beta}{(\xi / y)\left(1+\left|\varepsilon_{\xi, y}\right|\right)}
$$

Should condition (22) be violated, then fiscal austerity will be self-defeating. It will trigger a perverse "financial channel". In fact, as a consequence of austerity, the deficitto-GDP ratio will initially deteriorate, interest rates increase and investment shrink rather than take momentum. Interestingly, condition (22) is even the more binding, the higher the elasticity of primary deficit to capacity utilization $\left(\left|\varepsilon_{\xi, y}\right|\right)$, and the higher the initial level of the primary deficit over GDP $(\xi / y)$. The message to policy-makers is, 
therefore, the following: in the context of non-monetarily sovereign countries, it is of paramount importance to assess the effectiveness of austerity packages in prompting economic expansion before implementing them. It is even more important in the case of countries running quite large and "income-elastic" primary deficits. In these cases, even a mild austerity-led recession may give rise to a financial and economic disaster rather than improving macroeconomic records.

\subsection{The short-run macroeconomic effects of lower unemployment benefits}

Exercise 2 The government implements a cut in unemployment benefits $(\overline{\mathrm{w}})$ in order to induce wage moderation and engineer an internal devaluation of the real exchange rate.

The final goal of this policy is to improve the external competitiveness of the economy and boost growth via rising exports and a decrease in imports. In order to see if it is effective or not, take system (18) and differentiate it with respect to $d \bar{w}, d y$ and $d b$. We get:

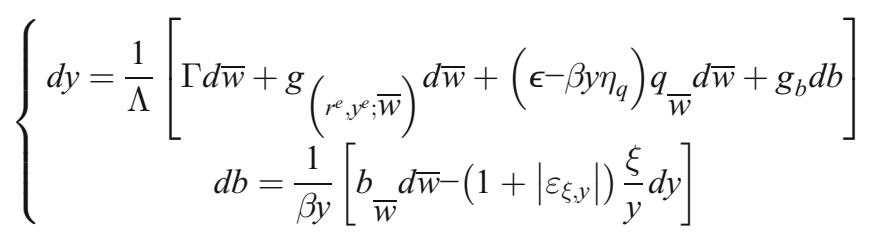

In system (23), $\Gamma=\left[\left(\partial c_{0} / \partial \bar{w}\right)-\beta \frac{(1-s)(1-t)}{\alpha}\right] \frac{(1-s)(1-t)}{\alpha}>0$ is the direct positive (negative) effect an increase (cut) in unemployment benefits would induce on capacity utilization by raising households' consumption. In the same vein, $g_{\left(r^{e}, y^{e} ; \bar{w}\right)}$ stands for the indirect effect a cut in unemployment benefits might have on investment demand $(g)$ by inducing a climate of wage moderation and, hence, by affecting firms' expected profit rate $\left(r^{e}\right)^{13}$ and capacity utilization $\left(y^{e}\right)$. Such an effect has an uncertain sign. On the one hand, according to EAT's supporters, a weaker trade union bargaining position, the redistribution of income in favor of firms, and hence higher expected profits $\left(r^{e}\right)$ can certainly encourage investment. On the other hand, investment's response to a reduction in unemployment benefits $(\bar{w})$ and the wage rate $(w)$ also depends on the impact such austerity measures bring about on expected capacity utilization $\left(y^{e}\right)$. A negative link between $\bar{w}, w$ and $y^{e}$ (i.e. a reduction in $\bar{w}$ and $w$ induces expected capacity utilization $y^{e}$ to rise) might perhaps emerge in extremely open small economies in which a minor part of aggregate demand comes from domestic absorption (the case of Ireland, for instance). However, such a relation likely turns out to be positive in large

\footnotetext{
${ }^{13}$ In the present paper, in equation (10) we do not explicitly formalize any specific link between expected (or desired) profitability and investment demand. Yet, any policy-induced one-off change in income distribution that, ceteris paribus, may also affect firms' profitability, can be modelled through an exogenous shift in the investment demand function itself. This is what we assume in system (23) when we analyze the short-run effects of a EAT-like cut in unemployment benefits and the ensuing climate of wage moderation.
} 
countries or in small but relatively closed economies such as Greece, in which domestic wages represent a leading source of aggregate demand. This is even the more so if one considers the positive link that may exist between higher wages and investment demand due to firms' search for new capital goods incorporating new labor-saving technologies (Fejio and Lamonica 2013; Caiani et al. 2017). In the end, the "EATfriendly" profit-led nature of investment demand is all to ascertain, hence the undefined sign associated to $g_{\left(r^{e}, y^{e} ; \bar{w}\right)} \cdot{ }^{14}$

Last but not least, in system (23) $b_{\bar{w}}=\frac{(1-t)}{\alpha \bar{w}} \frac{(1-t)}{\alpha \bar{w}}-t(\partial \omega / \partial \bar{\omega})$ is the variation in public deficit due to a change in unemployment benefits. If we take explicitly into account the sign of the variations in the policy variables at stake and we solve system (23), we get:

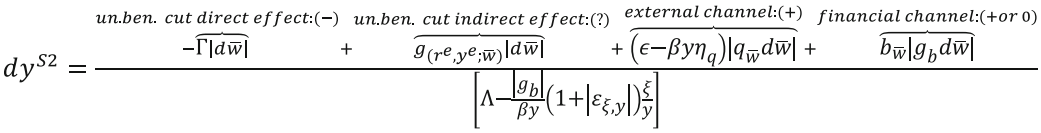

$$
d b^{S 2}=\frac{1}{\beta y}\left[b_{\bar{w}} d \bar{w}-\left(1+\left|\varepsilon_{\xi, y}\right|\right) \frac{\xi}{y} d y^{S 2}\right]
$$

Equations (24) and (25) confirm that even a well-designed cut in unemployment subsidies does not guarantee any success in stimulating growth (via internal devaluation and the "external channel") and/or squeezing the public deficit. In particular:

1. A reduction in $\bar{w}$ can lead, per se, to economic expansion only if $\left(\epsilon-\beta y \eta_{q}\right)\left|q_{\bar{w}}\right|$ $+g_{\left(r^{e}, y^{e} ; \bar{w}\right)}>\Gamma$, i.e. the "external channel", given the uncertain change in investment demand, is strong enough to outstrip the immediate reduction in private domestic consumption. Such an eventuality strongly relies upon the sensitiveness of net exports to the real exchange rate (parameters $\epsilon$ and $\eta_{q}$ in Eq. (24)), which, in turn, is conditional on the sectorial composition of net exports themselves and the degree of openness of the economy (see Taylor 1991). Fitting our theoretical analysis with the ongoing economic policy debate, we may say that it is highly questionable such a policy recipe could ever be successful in a relatively closed and largely deindustrialized small economy such as Greece.

2. As in Exercise 1, the effectiveness of cuts in unemployment benefits to trigger off a reduction in public deficit, and thus ignite virtuous financial mechanisms, strongly relies upon the pro-expansionary virtues of such a policy package. Point 1 already noted how this assumption could be extremely weak at beast.

\footnotetext{
${ }^{14}$ In standard post-Keynesian macro models à la Bhaduri and Marglin (1990), the profit-led or wage-led nature of capital accumulation hinges upon the positive effect current capacity utilization $(y)$ has on investment demand, and on the simultaneous determination of the two (i.e. $y$ and $g$ ) in the short run equilibrium. In the present model, the positive or negative response of capital accumulation to policy-induced shifts in income distribution depends on how a pro-profit change in income distribution alters entrepreneurs' expected capacity utilization $\left(y^{e}\right)$.
} 
Table 3 provides a summary of the results of the above policy experiments. It shows the high degree of uncertainty surrounding the allegedly expansionary outcomes of well-designed fiscal consolidation packages (see bold entries in Table 3 where $d y^{s}<0$ or not defined). In particular, Table 3 shows how, in the case of non-monetary sovereign countries, austerity packages risk to turn the "financial channel" negative (a (-) sign in Table 3) and to accentuate financial distress if they give rise to an initial economic contraction (due to rather weak expectation and external channels), which in turn deteriorates the solidity of public finances (condition (22) is not fulfilled).

\section{The long-run dynamics}

EAT's supporters have recently admitted that even well-designed austerity packages can actually come with some costs. Nevertheless, they maintain there are short-run and short-lived costs more than compensated by austerity-bred long-run benefits. According to Warmedinger et al. (2015), "the medium-to-longer-term benefits of well-designed fiscal consolidation are typically associated to short-term costs in the form of output losses, [but] since sound government finances are a prerequisite for price and macroeconomic stability and, consequently, for strengthening the conditions for sustainable growth, the long-term benefits of achieving such goals outweigh the shortterm costs" (Warmedinger et al. 2015, p.1).

In order to assess critically such a proposition, let us move our analysis to the longrun dynamics of the variables at stake, namely, capacity utilization (as determined by the evolution of economic actors' expectations) and the debt-to-GDP ratio. In this sense, it is worth reminding that our model is rather simple. In particular, it allows us not to take into account all the other economic and financial variables, say banks' deposits, foreign assets, and non-financial firms' private debt-to-GDP ratio, which also evolve through time on top of public debt-to-GDP ratio. The evolution of the private sector's financial wealth is not relevant because we have excluded any wealth effect from the determination of aggregate consumption. We also assume firms' investment decisions not to depend on the ratio between outstanding loans and capital stock. These are certainly relevant assumptions that may have relevant implications for the long-run dynamics of the model. For instance, the inclusion of any wealth effect or rentiers' consumption propensity in the definition of aggregate consumption would certainly help to stabilize the dynamics of the debt-to-GDP ratio. The inclusion of the private debt-to-capital stock ratio in the determination of firms' investments could determine a complex interaction between the evolution of private and public debt. ${ }^{15}$ Nonetheless, the above assumptions are functional to keep the analysis fairly simple and mathematically tractable. Furthermore, they keep our analysis focused on its main aim, i.e. a theoretical critique of intrinsic EAT contradictions. For this purpose, our model makes several concessions to EAT orthodoxy, in particular, its obsession about public debt

\footnotetext{
${ }_{15}$ An explicit formalization of the interaction between public and private debt, and of the way the latter can impact the evolution of the economy as a whole, certainly represents a central piece of a theoretical analysis of Minskian cyclical dynamics and instability. However, such an issue is beyond the goals of the present paper. Therefore, we preferred keeping this complication out of our theoretical model.
} 


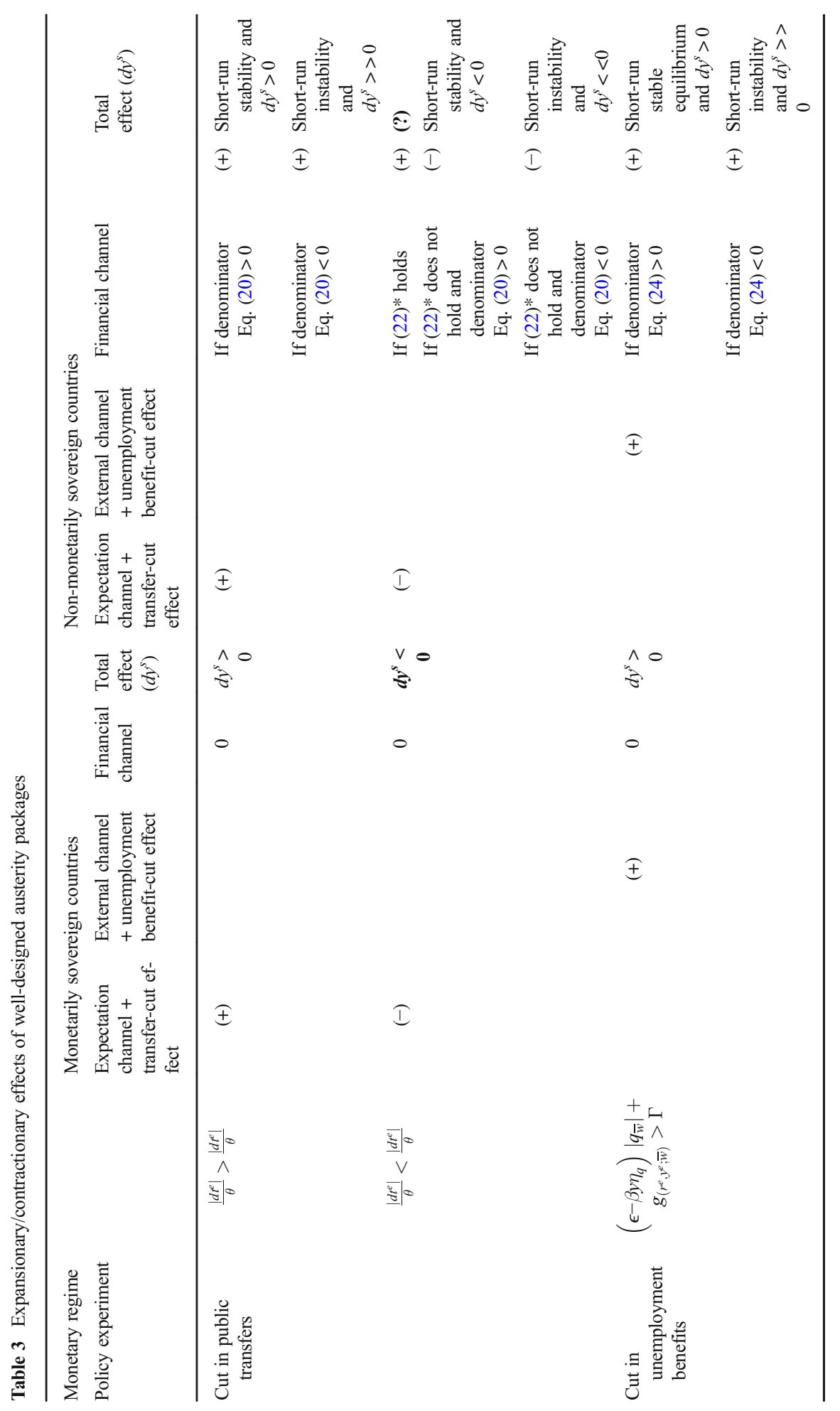




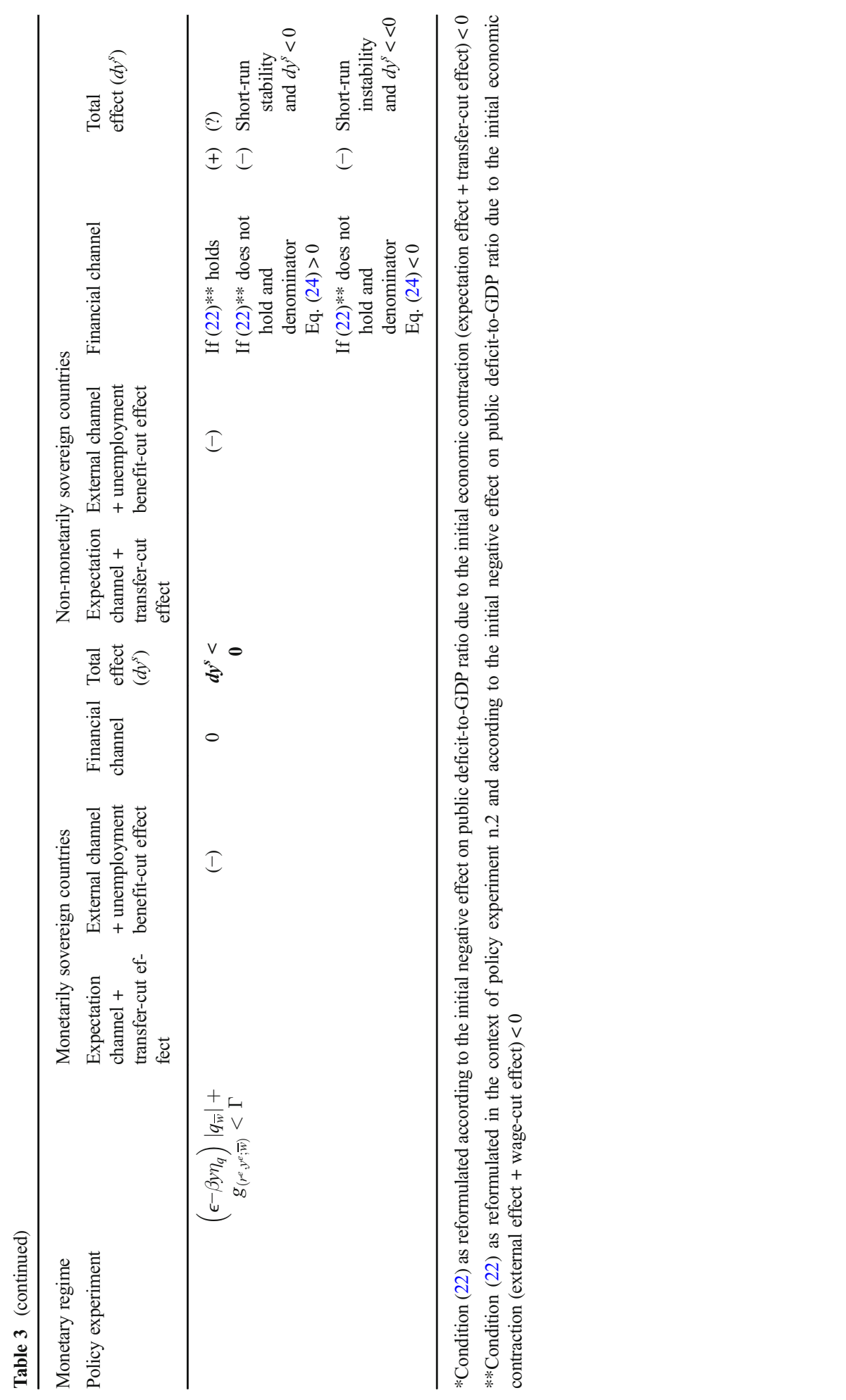


instability and its negative implication for economic activity, and to concentrate on the variables at the center of EAT argumentation.

According to EAT, expectations play a crucial role for austerity packages to be expansionary. Despite EAT's emphasis on economy-disruptive effects of excessive accumulation of unstable public debt, EAT-like theoretical models assume expectations to follow a forward-looking, perfect-foresight logic as elaborated by fully rational agents. Such theoretical apparatus significantly downgrades the degree of uncertainty affecting economic dynamics, since it excludes by assumption systemic risks perhaps due to public debt default. It also seems quite unrealistic and unable to describe the worldwide economic scenario emerging in the aftermath of the 2007-08 financial meltdown, and the eurozone sovereign debt crisis.

In the last decade, it may be more reasonable to think that economic decisions have been taken in a condition of deep substantive and procedural uncertainty (Dosi and Egidi 1991), at least in the eurozone. In such a climate of radical uncertainty, the best economic actors could (can) do was (is) to elaborate expectations in a myopic fashion. This is formally stated in Eq. (26), which models how non-financial firms' expectations evolve:

$$
\hat{y}^{e}=\phi\left(y-y^{e}\right)=\phi\left(y\left(y^{e}, \lambda\right)-y^{e}\right)
$$

Non-financial firms revise their expected level of capacity utilization upward, and hence set $\hat{y}^{e}>0$, when current capacity utilization $(y)$ turns out to be higher than expected. By contrast, should effective capacity utilization be lower than expected, expectations will be adjusted downwards. Two different stability scenarios may characterize the dynamics of expectations. On the one hand, a self-stabilizing adjustment process prevails if current economic activity, via desired investments, does not overreact to changes in expectations. See the Mathematical Appendix on this. Alternatively, the revision of expectations would be characterized by unstable knife-edge Harrodian dynamics.

With respect to the short-run model described above, in Eq. (26) we introduced an additional EAT-like assumption. Following Reinhart and Rogoff (2010), we assume that, on top of a higher deficit-to-GDP ratio, an increasing debt-toGDP ratio $\left(\lambda=D / P^{H} Y\right)$ also has a negative impact on economic activity, so that $\left(\frac{\partial y^{e}}{\partial \lambda}<0\right)$. In non-monetarily sovereign countries, a higher and supposedly riskier public debt stock may negatively impact commercial banks' balance sheets due to decreasing prices of sovereign bonds. This may lead commercial banks to search for higher "safety" margins on fundable projects and revise the mark-up rate $(\mu)$ upward. Ceteris paribus, commercial banks will charge higher interest rates $\left(i_{H}\right)$ on loans to the private sector. Widespread turbulences on the market for sovereign bonds may materialize, together with a credit crunch on the market for loans.

Equation (27) describes the dynamics of the debt-to-GDP ratio $(\lambda)$. After some mathematical passages, we get: 


$$
\begin{aligned}
\left(\frac{\hat{D}}{P^{H} Y}\right) & =\hat{\lambda}=\frac{d D}{D}-\hat{P}^{H}-\hat{Y}=\frac{(\xi+\psi) / \beta y}{\lambda}-\hat{P}^{H}-\hat{y}-\hat{K}=\hat{\lambda} \\
& =\frac{\xi\left(y\left(y^{e}\right) / \beta y\left(y^{e}\right)\right.}{\lambda}+\frac{\psi(\lambda) / \beta y\left(y^{e}\right)}{\lambda}-\left\{\varepsilon_{y, y^{y}} \hat{y}^{e}+\varepsilon_{y, i_{L}} \hat{i}_{L}(\lambda)+\left(1-\varepsilon_{y, q}\right) \hat{P}^{H}\left(y^{e}\right)+g\left(y^{e}, i_{L}\right)\right\}
\end{aligned}
$$

In Eq. (27), $\varepsilon_{y, y^{e}}=\left(g_{y^{e}} y^{e} / y\left(y^{e}, i_{H}\right)\right)$ is the elasticity of current capacity utilization $(y)$ to the expected one $\left(y^{e}\right) ; \varepsilon_{y, i_{H}}=g_{i_{H}} i_{h} / y\left(y^{e}, i_{H}\right)$ is $y$ 's elasticity to the interest rate $\left(i_{L}\right)$; $\varepsilon_{y, q}$ is $y$ 's elasticity to the real exchange rate. For the sake of simplicity, we assume both the nominal exchange rate $(e)$ and foreign prices $\left(P^{F}\right)$ to be given. Accordingly, in Eq. (27) the dynamics of the real exchange rate $(q)$ boils down to the percentage variation of domestic price level.

As to the stability properties of the debt-to-GDP ratio, it is first reasonable to think that when firms' expectations are more optimistic $\left(y^{e}\right)$, and hence current capacity utilization $(y)$ and investment $(\hat{K})$ increase, the debt-to-GDP ratio $(\lambda)$ decreases and its dynamics is stabilized. The effect that $\lambda$ may display on its own dynamics is trickier. Following Botta (2013), at relatively low levels of the debt-to-GDP ratio, a slightly higher value of the state variable $(\lambda)$ makes any additional public deficit less relevant in percentage terms. Accordingly, in Eq. (27), $\hat{D}$ turns out to be smaller. However, at much higher values of the debt stock, some of the concerns of the supporters of EAT might materialize. On the one hand, the higher is $\lambda$, the greater will be the burden of debt payments over GDP $(\psi) .{ }^{16}$ On the other hand, $\hat{i_{H}}$ may respond positively to a high and increasing debt-to-GDP ratio, due to the abovementioned intertwined dynamics between $\lambda$ and the interest rate on loans to the private sector. In the end, when financial operators start to fear, rationally or not, that $\lambda$ has reached excessively high levels, destabilizing forces may set in, passing through increasingly cumbersome repayment commitments, and the perverse economic effects supposedly unsafe public finances may trigger off in the form of increasing interest rates and plummeting economic activity. ${ }^{17}$ From a graphical point of view, the locus for a constant debt-to-GDP ratio $(\hat{\lambda}=0)$ may thus take the form of a U-shaped curve. In this sense, $\lambda_{T}$ stands for the dividing threshold of the debt-to-GDP ratio, above which financial operators believe destabilizing forces will mount. It represents the turning point after which the upward sloping arm of the locus for $(\hat{\lambda}=0)$ emerges. See the Mathematical Appendix on this.

Equations (26) and (27) jointly define an evolving economic system, in which a variety of different economic trajectories may emerge. Figures 1 and 2 describe the

\footnotetext{
$\overline{{ }^{16}}$ This effect comes both as a natural consequence of a higher debt stock, as well as a consequence of financial operators' assessments of the financial risks characterizing highly indebted economies. In the case of nonmonetarily sovereign countries, an increasing public debt stock can induce financial operators to raise the country factor risk $(\sigma)$, ask for higher interest rates $\left(i_{d}\right)$, and eventually make repayment conditions more stringent.

${ }^{17}$ In the analysis of equation (27), we have assumed that price dynamics and the evolution of the real exchange rate mutually compensate each other (i.e., $\varepsilon_{y, q}=1$ ). On the one hand, higher inflation reduces the real burden of the public debt stock. On the other, it may raise $\lambda$ by appreciating $q$, jeopardizing net exports, and eventually inducing a contractionary effect on current economic activity. For the sake of simplicity, we neglect to consider explicitly the direct and indirect effects $\hat{P^{H}}$ may play on $(\hat{\lambda})$.
} 


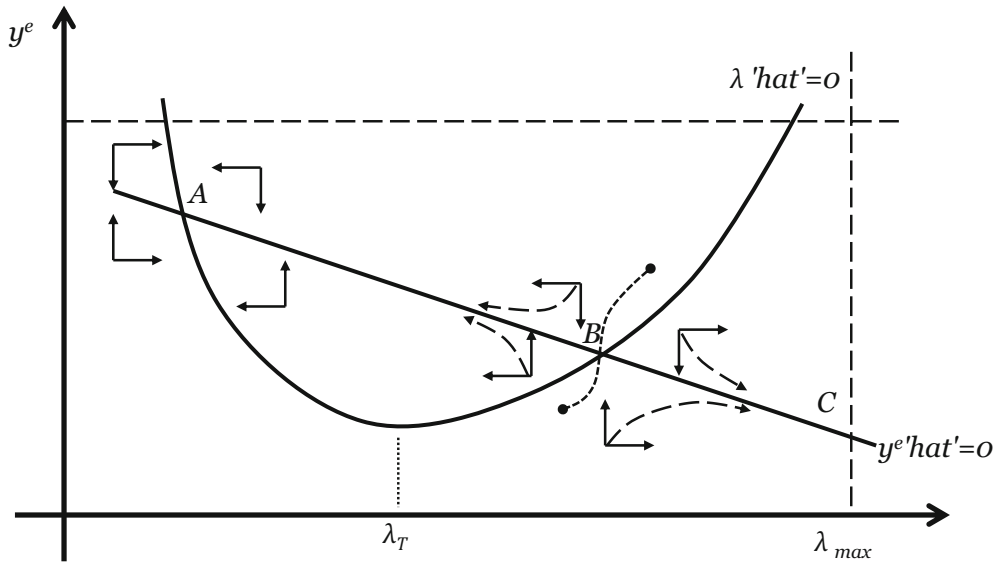

Fig. 1 Multiple equilibria in the $\left(y^{e}-\lambda\right)$ space with self-stabilizing expectations

economic meaningful cases in which multiple equilibria exist in in the $\left(y^{e}-\lambda\right)$ space. In Fig. 1, we describe the case of self-stabilizing forces prevailing in shaping the dynamics of expectations. Hence, the locus for $\left(\hat{y}^{e}=0\right)$ slopes downward. In Fig. 2, we portray the case for self-induced instability characterizing the dynamics of expectations. Accordingly, the locus for $\left(\hat{y}^{e}=0\right)$ is positively sloped. In Figs. 1 and 2, the vertical dashed line " $\lambda_{\max }$ " stands for the ceiling value of the debt-to-GDP ratio financial operators would agree to finance before rejecting additional treasury bond issuances, thus giving rise to sovereign debt default. Similarly, the horizontal dashed line represents the technology-bounded (highest) level expected and effective capacity utilization can reach.

The system we describe is far away from displaying the unique and stable equilibrium that usually characterizes EAT-like mainstream models populated by fully rational perfect-foresighted agents (see Bertola and Drazen 1990; Barry and Devereux 2003). In our model, path-dependence, cumulative mechanisms, and multiple equilibria dominate the scene. In Fig. 1, point $A$ represents a locally stable equilibrium featuring a high level

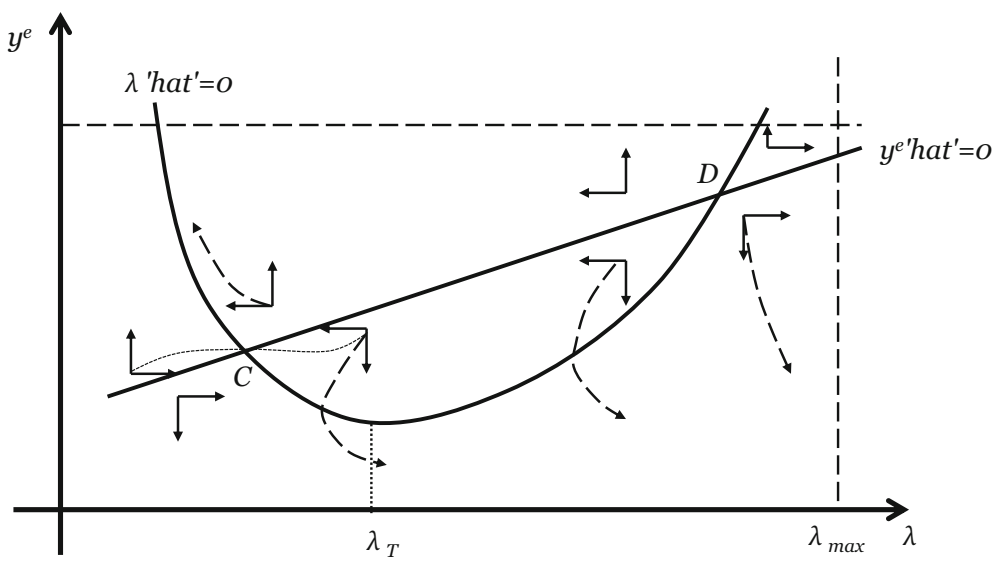

Fig. 2 Multiple equilibria in the $\left(y^{e}-\lambda\right)$ space with unstable expectations 
of capacity utilization and a low debt-to-GDP ratio. Nevertheless, point $B$ is a "perverse" unstable equilibrium, which combines low capacity utilization with a burdensome debt stock. On the right-hand side of point $B$, worrisome cumulative mechanisms get momentum. They can move the economy towards point $C$. At point $C$, financial markets eventually repudiate sovereign bonds, and public debt default takes place, causing a collapse in economic activity.

Such destabilizing forces are even stronger in Fig. 3. In this case, despite a relatively low debt-to-GDP level, even point $A$ shows saddle-path instability. In the absence of perfect-foresighted and optimizing agents, even a small deviation from point $A$ triggers off a diverging dynamics. In an optimistic scenario, booming economic activity could go hand-in-hand with a monotonically decreasing debt stock. Alternatively, the economy may embark on a far more worrisome path, along which collapsing expectations and economic activity mutually feedback into a mounting and unsustainable debt burden, eventually leading to a bankruptcy of the public sector.

\subsection{Short-run costs with long-run benefits? The intrinsic long-run inconsistency of EAT}

The economic scenarios portrayed in Figs. 1 and 2 well describe orthodoxy's concern about the accumulation of a too high public debt stock. Here comes our critique to EAT logic. Due to the very same concessions done to EAT orthodoxy, our model shows that austerity-led short-term costs (recession and an initial increase in debt-to-GDP ratio) cannot breed any long-run benefit. Short-run costs are intrinsically at odds with longrun improvements.

In order to see this, let us assume that the government implements a well-designed austerity package, which induces a modest recession in the short run and an initial deterioration in fiscal variables. In Fig. 3, such a contractionary fiscal policy shock

shifts the isocline for $(\hat{\lambda}=0)$ upward. Ceteris paribus, expected capacity utilization must increase in order to stabilize the debt-to-GDP ratio. At the same time, the isocline for $\left(\hat{y}^{e}=0\right)$ moves downward. The negative effect that a contractionary fiscal shock

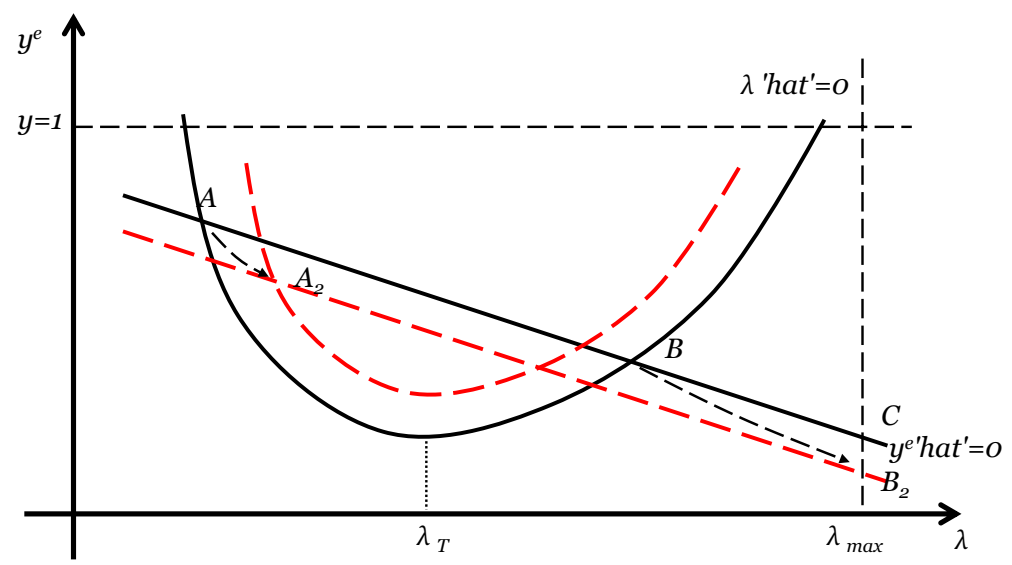

Fig. 3 Long-run outcomes of austerity-led short-run recessions in a stable dynamic scenario 


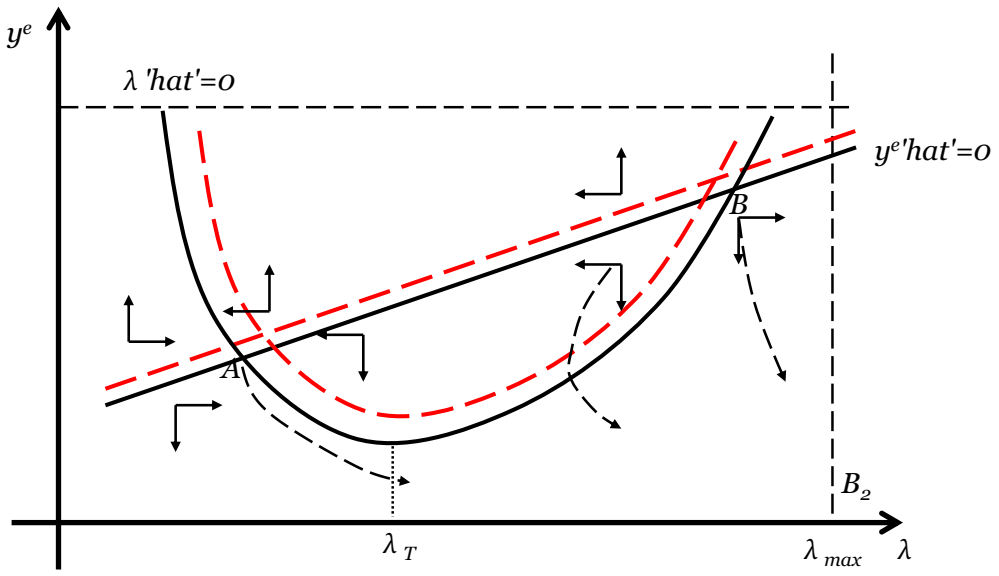

Fig. 4 Long-run outcomes of austerity-led short-run recession in an unstable dynamic scenario

bears on expectations' dynamics (via a reduction in current economic activity) must be compensated by a lower expected level of capacity utilization (since, in this scenario, expected capacity utilization has a self-stabilizing effect on its own dynamics). In Fig. 3 , should the economy be initially located at equilibrium point $A$, it will eventually end up at equilibrium $A_{2}$, featuring both depressed expected and effective economic activity (at least with respect to that associated with the initial equilibrium), and an increased debt burden. Even more worrisomely, should the economy be located in equilibrium $B$, an endless crisis and a mounting unsustainable debt stock eventually bring the economy towards an inevitable default (point $B_{2}$ in Fig. 3). Indeed, due to the short-run contractionary outcome of fiscal austerity, point $B$ does not constitute an equilibrium any longer. More than this, given the initial location of the economy on the unstable arm of the locus for $(\hat{\lambda}=0)$, short-run austerity-led economic contraction sets in destabilizing dynamics. Entrepreneurs' expectations are revised downwards, making the recession deeper and the debt-to-GDP ratio increase. The rise in the debt-to-GDP ratio feed backs negatively on economic activity and positively on its own dynamics. Whilst economic expectations and current capacity utilization shrinks continuously, the debt-to-GDP ratio rises until the threshold level $\lambda_{\max }$ is reached. At this point, financial operators repudiate public bonds and default takes place.

Such undesirable long-run outcomes of short-term austerity-led contractions arise even more easily in the radically unstable macroeconomic environment described in Fig. 4. In such a scenario, long-run instability would emerge even with an economy originally located at the apparently safe low-debt equilibrium point, $A$. Due to economic actors' expectations overreacting to fiscal policy shocks, even a slight upward shift in the isoclines for constant values of $\lambda$ and $y^{e}$ (see Fig. 4) ${ }^{18}$ will eventually induce a permanent contraction in economic activity and an unsustainable public-debt-to-GDP ratio.

\footnotetext{
$\overline{{ }^{18} \text { Due to the positive feedback } y^{e}}$ now carries out on its own dynamics, an increase in $y^{e}$ (an upward shift in the locus for $y^{e}=0$ ) is required to compensate for the austerity-induced contraction in $y$ and to keep $y^{e}=0$.
} 
More generally, the economy we describe may display explosive cumulative dynamics. This is the case of the debt-to-GDP ratio when government bonds are issued by non-monetarily sovereign countries; public debt sustainability is in the hands of financial market operators, and $\lambda$ eventually exceeds the stability thresholds financial operators have adopted as a shared but fragile convention. These non-linear, possibly cumulative dynamics are the source of path-dependence and multiple trajectories. A common aspect of these trajectories is that short-run austerity-led costs cause even larger pains (and no benefits) in the long run. This is why "a radical solution for high debt is [may be] to do nothing at all[and] just live with it" (Ostry and Ghosh 2015), at least when we come to consider tough fiscal retrenchments as an option for tackling it. Accordingly, EAT claims that short-run austerity-led costs can come with long-run benefits is intrinsically inconsistent, due to the very same mechanisms and dynamics at the base of EAT orthodoxy. Austerity must be expansionary in the short run to pay off in the long run. Unfortunately, we have seen at length how the former events (i.e., short-run austerity-led expansions) are very unlikely to happen.

\subsection{The case for endogenous monetary institutions}

In our model, country-specific institutions contribute to determining the short- and long-run outcomes of fiscal shocks. The specific rules guiding central bank flexibility in purchasing government bonds and taking action against financial distress crucially modify how austerity may affect economic activity, and the evolution of public deficit and debt.

In the short run, the degree of monetary sovereignty of an economy contributes to defining the active channels through which fiscal consolidation might deliver expansionary outcomes. In monetarily sovereign countries, the central bank can easily buy government bonds in order to backstop any extraordinary fiscal effort against economic and financial crises. Accordingly, the "financial channel" is likely irrelevant. The "financial channel" may be operative in non-monetarily sovereign countries. However, its effectiveness is contingent upon the highly debatable capacity of austerity measures to prompt economic expansions and to squeeze the public deficit (and debt) from the very beginning.

The degree of monetary sovereignty can fundamentally alter the long-run stability of the economy. In monetarily sovereign countries, the domestic central bank can neutralize the negative effects that an increasing debt-to-GDP ratio may have on the economy through its active intervention on financial markets. In monetarily sovereign countries, monetary authorities can effectively eliminate, or at least tame, the destabilizing forces that a fast-rising public debt stock may bear on its own dynamics via $\psi$ and $\hat{i_{H}}$ (see Eq. (27)). From a graphical point of view (see Fig. 1), this amounts to removing the upward sloping part of the locus for $(\hat{\lambda}=0)$, or at least making it emerge at a far higher $\lambda_{T}$ value, and with a much flatter slope. Full monetary sovereignty can significantly expand the "safe" stability zone surrounding point $A$ in Fig. 1. By the same token, the lack of monetary sovereignty constitutes a fundamental source of financial fragility, as eurozone experience in the last decade has vividly showed. 


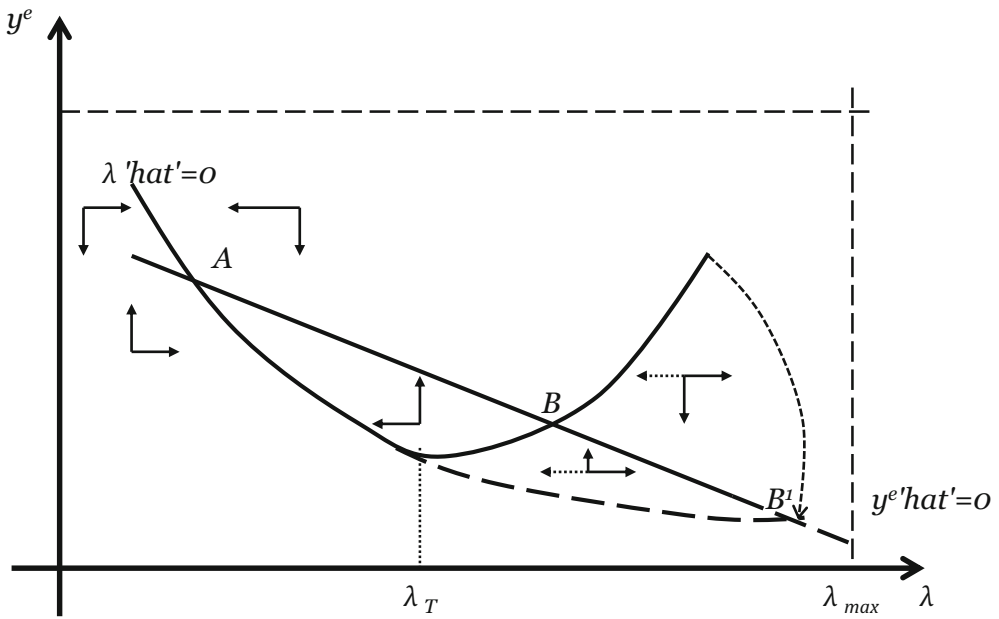

Fig. 5 Stabilizing macroeconomic effects of monetary sovereignty

In this model, we presented such an institutional dichotomy as exogenously given, and captured by the binary time-invariant parameter $(\Omega)$. Nonetheless, the events taking place in the eurozone since 2012 demonstrate that institutions, monetary institutions among them, can co-evolve through time together with "pure" economic variables.

The 2007-08 financial crisis initially emerged as an external shock to euro countries. Due to the peculiar features or, better, the shortcomings of the eurozone institutional building, a private debt crisis then evolved into a sovereign debt crisis. The increasing risk of a eurozone suicide eventually led the ECB to pursue a gradual and partial, yet important, drift towards an embryonic (and path-dependent) form of monetary sovereignty. ${ }^{19}$ Mario Draghi's "whatever it takes" statement and the launch of the outright monetary transactions (OMT) program, may constitute good examples of endogenous institutional changes (Lordon 1997) inspired by the intrinsic dynamics of the system, and by the very same economic issues they aim to tackle.

The effects of such a change are well known. Since mid-2012, hikes in the interest rates of sovereign bonds issued by peripheral eurozone countries have disappeared, and financial operators have stopped obsessively scrutinizing the solidity of public finances of peripheral countries. Figure 5 portrays the stabilizing forces sparked in the eurozone by such endogenous institutional changes.

Let us assume that the worldwide "Great Recession" and the rescue packages of domestic financial institutions cause public deficits and public debts to rise suddenly. Let us also assume that the debt-to-GDP ratio overcome the "stability threshold" $\lambda_{T}$. In the absence of any significant change, financial turbulences would mount and the public sector be on the verge of bankruptcy. The extraordinary measures taken by the ECB board at the height of the crisis represent the endogenous institutional response to such an apparently inevitable end. In Fig. 5, the upward-sloping arm of the locus for

\footnotetext{
${ }^{19}$ Path dependency here consists in the peculiar institutional arrangements the euro system adopted in 2012 in order to definitively snap-off financial turbulences given the legal and political constraints to ECB's actions and the lack of a centralized eurozone fiscal authority.
} 
$(\hat{\lambda}=0)$ moves downward and changes slope. The isocline for constant values of the debt-to-GDP ratio $(\lambda)$ is transformed into a prevalently downward-sloping locus. Point B shifts to point $B^{l}$, and the destabilizing forces on the right of point $B$ are inverted into stabilizing ones (see newly emerging dotted arrows). Peripheral eurozone countries that were reining against a seemingly unavoidable default can now rejoin stability, and gradually converge back to point $\mathrm{A}$.

\section{Conclusions}

An increasing body of orthodox analyses admits that front-loaded fiscal retrenchments can likely cause an economic recession and an increasing debt-to-GDP ratio (Gros 2012; Ali Abbas et al. 2013; Warmedinger et al. 2015) in the short run. Nonetheless, this literature also maintains that recession and an initially rising debt-to-GDP ratio are necessary short-run costs in order to reap much higher benefits in the long run. In this paper, we show how this proposition is theoretically inconsistent. In a post-Keynesian/ evolutionist model that makes several concessions to EAT logic, we show how these very same concessions to orthodoxy require austerity to be expansionary and to reduce public debt from the very beginning in order to pay off in the long run. However, such an expansionary outcome of supposedly well-designed austerity packages is highly uncertain from a theoretical point of view. In the end, there are good theoretical reasons to believe that even well-designed fiscal consolidations may likely be self-defeating.

In light of these findings, the right policy recipe against sovereign debt crisis, and the right timing for implementing it, looks radically different from what has effectively been done so far. In the case of highly indebted non-monetarily sovereign economies such as Greece, macroeconomic stability and growth can be primarily achieved through significant debt relief. Instead of waiting, as the ECB did before intervening in July of 2012, monetary institutions should take immediate and decisive action to strike financial speculation and to neutralize the mounting debt crisis. This would give national governments more space for gradually maneuvering to less painful reform of their economies in a more stable environment. Only subsequently could some mild austerity measures be considered in those (few) countries dealing with some problems of fiscal profligacy.

Following Eichengreen and Panizza (2014), adjustment programs that are too ambitious and prolonged are hardly implementable. They also fail to recognize that significant reductions in the debt burden have historically occurred during periods of high growth. If growth is the main way out of the crisis, and one does not want to consider expansionary fiscal policies openly, attention should at least focus on public support for policies related to industry, innovation, and investment. Public investment banks, if not governments directly, may turn out to be decisive actors to prompt a sustained and sustainable recovery.

\section{Compliance with ethical standards}

Conflict of interest The authors declare that they have no conflict of interest. 


\section{Mathematical Appendix}

Equations (26) and (27) form a system of two dynamic equations, the stability properties of which can be analyzed by taking partial derivatives of both equations with respect to $\left(y^{e}\right)$ and $(\lambda)$ in correspondence to the steady state (i.e. when $\left(y^{e}=0\right)$ and $(\lambda=0))$. Take Eq. (26) first. We have:

$$
B=y^{e}=\phi y^{e}\left(y\left(y^{e}, \lambda\right)-y^{e}\right)
$$

By taking the above expression in the steady state, totally differentiating it with respect to $\left(y^{e}\right)$ and $(\lambda)$, and taking partial derivatives, we have:

$$
\dot{d y} \dot{y}^{e}=\phi y^{L R}\left(\frac{g_{y^{e}}}{\Lambda}-1\right) d y^{e}+\phi y^{L R} \frac{g_{\lambda}}{\Lambda} d \lambda=0
$$

With $\frac{g_{y^{e}}}{\Lambda}>0$ and $\frac{g_{\lambda}}{\Lambda}<0$.

Rearranging Eq. (28) a bit, we get:

$$
\left.\frac{d y^{e}}{d \lambda}\right|_{y^{e}=0}=-\frac{\frac{g_{\lambda}}{\Lambda}}{\left(\frac{g_{y^{e}}}{\Lambda}-1\right)}
$$

The sign of Eq. (29) can be negative or positive depending on the sign of the denominator. Should $\frac{g_{v e}}{\Lambda}$ be lower than 1 and the denominator of Eq. (29) negative (current capacity utilization does not overact to changes in expectations), then the slope of the geometric locus for constant values of expected and current capacity utilization is negative. Should $\frac{g_{v e}}{\Lambda}$ be larger than 1 and the denominator of Eq. (29) positive (current capacity utilization overacts to changes in expectations in a Harrodian fashion), then the slope of the geometric locus for $y^{e}=y$ and $\left(y^{e}=0\right)$ gets positive.

When we move to Eq. (27), after assuming that $\varepsilon_{y, q}=1$, we get:

$$
\dot{\lambda}=\lambda H=\lambda\left\{\frac{\xi\left(y\left(y^{e}\right) / \beta y\left(y^{e}\right)\right.}{\lambda}+\frac{\psi(\lambda) / \beta y\left(y^{e}\right)}{\lambda}-\left[\varepsilon_{y, y^{e}} \hat{y}^{e}+\varepsilon_{y, i_{L}} \hat{i}_{L}(\lambda)+g\left(y^{e}, i_{L}\right)\right]\right\}
$$

(With) $H=\left\{\frac{\xi\left(y\left(y^{e}\right) / \beta y\left(y^{e}\right)\right.}{\lambda}+\frac{\xi\left(y\left(y^{e}\right) / \beta y\left(y^{e}\right)\right.}{\lambda}-\left[\varepsilon_{y, y^{e}} \hat{y}^{e}+\varepsilon_{y, i_{L}} \hat{i}_{L}(\lambda)+g\left(y^{e}, i_{L}\right)\right]\right\}$

Imposing equilibrium and evaluating partial derivatives at the steady state, we get:

$$
d \dot{\lambda}=\left.\lambda^{L R} \frac{\partial H}{\partial \lambda}\right|_{\lambda=0} d \lambda+\left.\lambda^{L R} \frac{\partial H}{\partial y^{e}}\right|_{\lambda=0} d y^{e}
$$


With:

$$
\begin{aligned}
\left.\frac{\partial H}{\partial \lambda}\right|_{\lambda=0}= & -\frac{\xi / \beta y}{\left(\lambda^{L R}\right)^{2}} \\
& +\frac{(\partial \psi / \partial \lambda) \lambda^{L R}-\psi}{\beta y\left(\lambda^{L R}\right)^{2}}-\varepsilon_{y, y^{e}} \phi y^{L R}\left(g_{\lambda} / \Lambda\right)-\varepsilon_{y, i_{L}}\left(\partial \hat{i}_{L} / \partial \lambda\right)-g_{i_{L}}\left(\partial i_{L} / \partial \lambda\right)
\end{aligned}
$$

And

$$
\left.\frac{\partial H}{\partial y^{e}}\right|_{\lambda=0}=\frac{[(\partial \xi / \partial y) \beta y-(\xi+\psi) \beta]\left(\partial y / \partial y^{e}\right)}{\lambda^{L R}(\beta y)^{2}}-g_{y^{e}}-\varepsilon_{y, y^{e}} \phi y^{L R}\left(\frac{g_{y^{e}}}{\Lambda}-1\right)
$$

It is reasonable to assume that $(\partial \psi / \partial \lambda),\left(\partial \hat{i_{L}} / \partial \lambda\right)$ and $\left(\partial i_{L} / \partial \lambda\right)$ are always positive but small and close to zero when $\lambda \longrightarrow 0$. Instead, they may considerably rise when the debt-to-GDP ratio increases to what economic agents may consider as too high and perhaps unsustainable levels. Accordingly, we get:

$$
\begin{aligned}
& \left.\lim _{\lambda \rightarrow 0} \frac{\partial \dot{\lambda}}{\partial \lambda}\right|_{\lambda=0}=-\frac{\xi / \beta y}{\lambda^{L R}}+\frac{(\partial \psi / \partial \lambda)}{\beta y}-\frac{\psi}{\lambda^{L R}}-\lambda^{L R}\left[\varepsilon_{y, y^{e}} \phi y^{L R}\left(g_{\lambda} / \Lambda\right)+\varepsilon_{y, i_{L}}\left(\partial \hat{i}_{L} / \partial \lambda\right)+g_{i_{L}}\left(\partial i_{L} / \partial \lambda\right)\right]=-\infty \\
& \left.\lim _{\lambda \rightarrow \infty} \frac{\partial \dot{\lambda}}{\partial \lambda}\right|_{\lambda=0}=-\frac{\xi / \beta y}{\lambda^{L R}}+\frac{(\partial \psi / \partial \lambda)}{\beta y}-\frac{\psi}{\lambda^{L R}}-\lambda^{L R}\left[\varepsilon_{y, y^{e}} \phi y^{L R}\left(g_{\lambda} / \Lambda\right)+\varepsilon_{y, i_{L}}\left(\partial \hat{i}_{L} / \partial \lambda\right)+g_{i_{L}}\left(\partial i_{L} / \partial \lambda\right)\right]=\infty
\end{aligned}
$$

It is also reasonable to think that the sign of Eq. (32), and hence of $\left.\frac{\partial \lambda}{\partial y^{e}}\right|_{\lambda=0}$, is negative. An increase in expected capacity utilization stabilizes the debt-to-GDP ratio by expanding current economic activity and boosting the growth rate of capital stock. ${ }^{20}$ All in all, we deal with a U-shaped locus for constant values of the debt to GDP ratio, with a minimum point at $\lambda^{T}$ :

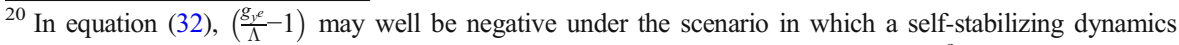
describes time variations of expected capacity utilization. Accordingly, an increase in $y^{e}$ might have a partial positive effect on the dynamics of the debt-to-GDP ratio. This fact notwithstanding, it is unreasonable to think such a positive effect might outstrip the negative ones described in the main text, so that $\left.\left(\partial \dot{\lambda} / \partial y^{e}\right)\right|_{\lambda=0}$ likely remains negative.
} 


$$
\begin{aligned}
\left.\frac{\partial \dot{\lambda}}{\partial \lambda}\right|_{\lambda=0 \text { and } \lambda=\lambda^{T}} & =\left[\varepsilon_{y, y^{e}} \phi y^{L R}\left|g_{\lambda} / \Lambda\right|+\left|\varepsilon_{y, i_{L}}\right|\left(\partial \hat{i}_{L} / \partial \lambda^{T}\right)+\left|g_{i_{L}}\right|\left(\partial i_{L} / \partial \lambda^{T}\right)+\frac{\left(\partial \psi / \partial \lambda^{T}\right)}{\beta y}\right] \\
& -\left[\frac{\xi / \beta y}{\lambda^{T}}+\frac{\psi\left(\lambda^{T}\right)}{\lambda^{T}}\right]=0
\end{aligned}
$$

In such a context, multiple equilibria emerge when $y^{e}\left(\lambda^{T}\right): \dot{\lambda}=0 \leq y^{e}\left(\lambda^{T}\right): y^{e}=0$, and $\left(\frac{g_{y} e}{\Lambda}-1\right) \neq 0$. Many different dynamics emerge depending on how expected capacity utilization feeds back into its own dynamics.

1. Self-stabilizing dynamics in the evolution of expected capacity utilization, i.e. $\frac{g_{y} e}{\Lambda}<1$.

According to Fig. 1, two long-run equilibria exist with different stability properties. On the on hand, equilibrium $A$ is characterized by the Jacobian matrix $J^{A}$ reported below:

$$
J^{A}=\left[\begin{array}{ll}
\left.\frac{\partial \dot{y}^{e}}{\partial y^{e}}\right|_{y^{e}=0} & \left.\frac{\partial \dot{y}^{e}}{\partial \lambda}\right|_{\underline{y}^{e}=0} \\
\left.\frac{\partial \dot{\lambda}}{\partial y^{e}}\right|_{\lambda=0} & \left.\frac{\partial \dot{\lambda}}{\partial \lambda}\right|_{\lambda=0}
\end{array}\right]
$$

All four entries in matrix $J^{A}$ have a negative sign. The trace tr. $\left(J^{A}\right)$ is surely negative. Equilibrium $A$ will be locally stable if $\operatorname{det} .\left(J^{A}\right)>0$. Mathematically, we have:

$\operatorname{det} .\left(J^{A}\right)=\frac{\partial \dot{y}^{e}}{\partial y^{e}} \frac{\partial \dot{y}^{e}}{\partial y^{e}}-\frac{\partial \dot{y}^{e}}{\partial y^{e}} \frac{\partial \dot{y}^{e}}{\partial y^{e}}>0$, i.e. $\frac{\partial \dot{y}^{e}}{\partial y^{e}} \frac{\partial \dot{y}^{e}}{\partial y^{e}}>\frac{\partial \dot{y}^{e}}{\partial y^{e}} \frac{\partial \dot{y}^{e}}{\partial y^{e}}$. Taking the absolute value of the partial derivatives included in the Jacobian matrix $J^{A}$ and rearranging, we get: $\operatorname{det} .\left(J^{A}\right)>0$ if $\frac{|(\partial \lambda / \partial \lambda)|}{\left|\left(\partial \lambda / \partial y^{e}\right)\right|}>\frac{|(\partial \lambda / \partial \lambda)|}{\left|\left(\partial \lambda / \partial y^{e}\right)\right|}$, i.e. the locus for a constant debt-to-GDP ratio is steeper (in absolute value) with respect to the locus for a constant expected capacity utilization. In Fig. 1, equilibrium $A$ satisfies these conditions, so that it stands out as locally stable.

Jacobian matrix $J^{B}$ determines the dynamics in the neighborhood of equilibrium $B$ :

$$
J^{B}=\left[\begin{array}{cc}
\left.\frac{\partial \dot{y}^{e}}{\partial y^{e}}\right|_{y^{e}=0} & \left.\frac{\partial \dot{y}^{e}}{\partial \lambda}\right|_{\underline{y}^{e}=0} \\
\left.\frac{\partial \dot{\lambda}}{\partial y^{e}}\right|_{\lambda=0} & \left.\frac{\partial \dot{\lambda}}{\partial \lambda}\right|_{\lambda=0} \\
+
\end{array}\right]
$$

In the Jacobian matrix $J^{B},\left.(\partial \dot{\lambda} / \partial \lambda)\right|_{\lambda=0}$ becomes positive so that $\operatorname{det} .\left(J^{B}\right)<0$, and saddle-path instability emerges. 
2. Explosive dynamics in the evolution of expected capacity utilization, i.e. $\frac{g_{y} e}{\Lambda}>1$.

Figure 2 portrays the case of destabilizing forces driving the dynamics of expected capacity utilization (i.e. the locus for $\left(y^{e}=y\right)$ is upward sloped). Again, multiple equilibria may emerge with different stability properties. The Jacobian matrix $J^{C}$ determines economy's dynamics in the neighborhood of equilibrium $C$ :

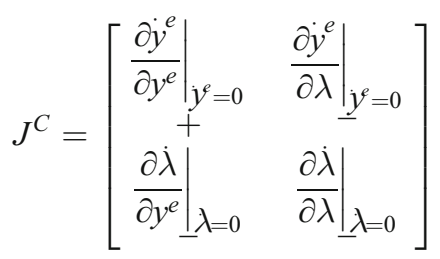

It is easy to see that the $\operatorname{det} .\left(J^{C}\right)$ is certainly negative, since $-\frac{(\partial \lambda / \partial \lambda)}{\left(\partial \lambda / \partial y^{e}\right)}<-\frac{(\partial \lambda / \partial \lambda)}{\left(\partial \lambda / \partial y^{e}\right)^{\circ}}$. Accordingly, two eigenvalues exist with opposite signs, and saddle-path instability characterizes equilibrium $C$.

Last but not least, the Jacobian matrix $J^{D}$ is associated to equilibrium $D$ in Fig. 2:

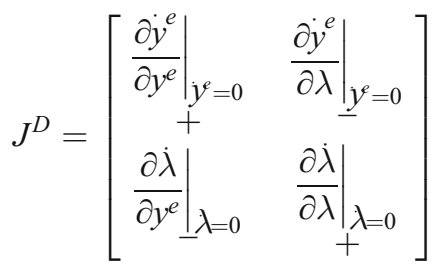

In this case, both trace $\operatorname{tr} .\left(J^{D}\right)$ and determinant det. $\left(J^{D}\right)$ are positive, since that $t r$. $\left(J^{D}\right)=\frac{\partial \dot{y}^{e}}{\partial y^{e}}+\frac{\partial \dot{y}^{e}}{\partial y^{e}}>0$ and $-\frac{(\partial \dot{\partial} / \partial \lambda)}{\left(\partial \lambda / \partial y^{e}\right)}>-\frac{(\partial \dot{\partial} / \partial \lambda)}{\left(\partial \lambda / \partial y^{e}\right)}$ (i.e. det. $\left.\left(J^{D}\right)>0\right)$. It is clear that radical instability emerges in the neighborhood of equilibrium D.

Open Access This article is distributed under the terms of the Creative Commons Attribution 4.0 International License (http://creativecommons.org/licenses/by/4.0/), which permits unrestricted use, distribution, and reproduction in any medium, provided you give appropriate credit to the original author(s) and the source, provide a link to the Creative Commons license, and indicate if changes were made.

\section{References}

Alesina A (2010) Fiscal adjustments: lessons from recent history. Paper prepared for the EU Ecofin meeting in Madrid

Alesina A, Ardagna S (2010) Large changes in fiscal policy: tax versus spending. In: Brown JR (ed) Tax policy and the economy. University of Chicago Press, Chicago 
Alesina A, Ardagna S (2012) The Design of Fiscal Adjustments, NBER working paper no. 8423. National Bureau of Economic Research, Cambridge

Alesina A, Favero C, Giavazzi F (2015) The output effects of fiscal consolidation plans. J Int Econ 96(supplement 1):S19-S42

Alesina A, Perotti R (1995) Fiscal expansions and fiscal adjustments in OECD countries, NBER Working Paper no. 5214. National Bureau of Economic Research, Cambridge

Alesina A, Perotti R (1997) Fiscal adjustments in OECD countries: composition and macroeconomic effects. IMF Staff Pap 44(2):210-248

Ali Abbas A, Akitoby B, Andritzki J, Berger H, Komatsuzaki T, Taylor J (2013) Dealing with high debt in an era of low growth, IMF Staff Discussion Note 13/07. International Monetary Fund, Washington, DC

Baker D, Rosnick D (2014) Stimulus and fiscal consolidation: the evidence and implications, IMK working paper no. 135. Hans Böckler Foundation, Düsseldorf

Barry F, Devereux MB (2003) Expansionary fiscal contraction: a theoretical explanation. J Macroecon 25(1):1-23

Bertola G, Drazen A (1990) Trigger points and budget cuts: explaining the effects of fiscal austerity, NBER working paper no. 3844. National Bureau of Economic Research, Cambridge

Bhaduri A, Marglin S (1990) Unemployment and the real wage: the economic basis for contesting political ideology. Camb J Econ 14(4):375-393

Botta A (2013) Fiscal policy, Eurobonds, and economic recovery: heterodox policy recipes against financial instability and sovereign debt crisis. J Post-Keynesian Econ 35(3):417-441

Boyer R (2012) The four fallacies of contemporary austerity policies: the lost Keynesian legacy. Camb J Econ 36(1):283-312

Caiani A, Russo A, Gallegatti M (2017) Are high wage good for business? an assessment under alternative innovation and investment scenarios. Munich Personal Repec Archive (MPRA) working paper n. 80439

De Grauwe P (2011) Managing a fragile eurozone. CESifo Forum 12(2):40-45

De Grauwe P, Ji Y (2013) Self-fulfilling crises in the Eurozone: an empirical test. J Int Money Financ 34:15-36

Dosi G, Egidi M (1991) Substantive and procedural uncertainty - an exploration of economic behavior in changing environments. J Evol Econ 1(2):145-168

Dosi G, Napoletano M, Roventini A, Treibich T (2015) The short- and long-run damages of fiscal austerity: Keynes beyond Schumpeter. In: Stiglitz JE, Guzman M (eds) Contemporary issues in macroeconomics. Lessons from the crisis and beyond. Palgrave MacMillan, Basingstoke

Dutt AK (2013) Government spending, aggregate demand and economic growth. Rev Keynesian Econ 1(1): 105-119

Eichengreen B, Panizza U (2014) A surplus of ambition: can Europe rely on large primary surpluses to solve its debt problem? NBER working paper no. 20316. National Bureau of Economic Research, Cambridge

Fejio CA, Lamonica MT (2013) A Kaldorian approach to catch-up and structural change in economies with a higher degree of heterogeneity. PSL Q Rev 66(265):107-135

Foresti P, Marani U (2014) Expansionary fiscal consolidations: theoretical underpinnings and their implications for the eurozone. Contrib Pol Econ 33(1):19-33

Giavazzi F, Pagano M (1990) Can severe fiscal contractions be expansionary? Tales of two small European countries. NBER Macroecon Annu 5:75-122

Giavazzi F, Pagano M (1996) Non-Keynesian effects of fiscal policy changes: international evidence and the Swedish experience. Swed Econ Pol Rev 39(3):635-657

Godley W, Lavoie M (2007) Fiscal policy in a stock-flow-consistent (SFC) model. J Post Keynesian Econ 30(1):79-100

Gros D (2012) Can austerity be self-defeating? Credible austerity plans are required. Intereconomics 47(3): 175-177

Guajardo J, Leigh D, Pescatori A (2011) Expansionary austerity: new empirical evidence, IMF working paper no. 158. International Monetary Fund, Washington, DC

Hein E (2016) Autonomous government expenditure growth, deficits, debt and distribution in a neo-Kaleckian growth model. IPE working paper n. 68/2016

Leao P (2013) The effect of government spending on the debt-to-GDP ratio: some Keynesian arithmetic. Metroeconomica 64(3):448-465

Lordon F (1997) Endogenous structural change and crisis in a multiple time-scales growth model. J Evol Econ 7(1):1-21

Mehrling P (2011) The new Lombard street. How the fed became a dealer of last resort. Princeton University Press, Princeton

Ostry JD, Ghosh AR (2015) When is Repaying Public Debt Not of the Essence?" Blog post, IMF Direct. Available at: https://blog-imfdirect.imf.org/2015/06/02/when-is-repaying-public-debt-not-of-the-essence/ 
Palley T (2010) The simple macroeconomics of fiscal austerity, public sector debt and deflation, IMK working paper no. 8/2010. Hans Böckler Foundation, Düsseldorf

Perotti R (2013) The 'austerity myth': gain without pain? In: Alesina A, Giavazzi F (eds) Fiscal policy after the financial crisis. University of Chicago Press, Chicago

Radzicki MJ, Sterman JD (1994) Evolutionary economics and system dynamics. In: England RW (ed) Evolutionary concepts in contemporary economics. The University of Michigan Press, Ann Arbor

Reinhart CM, Rogoff KS (2010) Growth in a time of debt. Am Econ Rev Pap Proc 100:573-578

Ryoo S, Skott P (2013) Public debt and full employment in a stock-flow-consistent model of a corporate economy. J Post Keynesian Econ 37(4):511-527

Sutherland A (1997) Fiscal crises and aggregate demand: can high public debt reverse the effect of fiscal policy? J Public Econ 65(2):147-162

Taylor L (1991) Income distribution, inflation and growth: lectures on Structuralist macroeconomic theory. MIT Press, Cambridge

Taylor L (2012) Growth, cycles, asset prices and finance. Metroeconomica 63(1):40-63

Warmedinger T, Checherita-Westphal C, Hernandez de Cos P (2015) Fiscal multipliers and beyond, ECB occasional paper series no.162/June 2015. European Central Bank, Frankfurt

You J, Dutt AK (1996) Government debt, income distribution and economic growth. Camb J Econ 20(3):335-351 